\title{
Review of $24^{\text {th }}$ Seoul IAPD Congress
}

\author{
Sangho Lee \\ Department of Pediatric Dentistry, School of Dentistry, Chosun University \\ Local Organizing Committee of 2013 Seoul IAPD Congress
}

\section{Abstract}

The Korean Academy of Pediatric Dentistry hosted the 24 ${ }^{\text {th }}$ IAPD Congress in Seoul, Korea on June 12-15, 2013. The main theme of the congress was the "New visions in Pediatric Dentistry"

A total number of 1,855 participants, including exhibitors and press from 67 countries, participated in the 24th IAPD Congress. The scientific program consists of 85 invited lectures, 126 oral presentations, and 553 poster presentations. 46 companies and organizations have supported and participated in Seoul IAPD Congress.

Overall the congress was a success in terms of high attendance rate from 67 countries over the world. Considering the fact that Korea is located in the far-east, the number of overseas delegates (943) are remarkable. Also it is desirable to have over 100 delegates from developing countries which eventually aim to collaborate worldwide.

The scientific program covered a variety of topics and many of the delegates stayed in the session room until the last day of the congress. Although it could have been more beneficial to allot more time for each speaker to discuss further, the program fit the Congress theme "New Visions for Paediatric Dentistry".

All social event tickets were sold out early and it attracted participants with interesting program enabling participants to interact and exchange ideas outside of the meeting.

Key words : IAPD, Congress, Seoul, Pediatric Dentistry

\section{I. 서 론}

대한소아치과학회가 주관한 제 24회 세계소아치과학회가 서 울 코엑스에서 2013년 6월 12일부터 15일 까지 4일간 성황리 에 개최 되었다. 이번 세계학회는 대회 등록자 67 개국 1,885 명 (후원/전시업체 참가자 포함), 일반 연제 발표 756건 이란 역 대 대회사상 최고의 기록을 수립하는 양적인 성과를 기록하였 다. 또한 학술프로그램의 내용과 대회의 운영 면에서도 모든 참 가자에게 좋은 평가를 받아 질적인 면에서도 성공을 거둔 대회 였다.

대한소아치과학회는 이번 세계학회를 통해 우리 학회의 높은
학문적, 임상적 수준, 유구한 전통, 탄탄한 조직력을 세계에 알 리며, 세계무대의 중심으로 일보 더 전진하였다. 이번 세계학회 의 성과가 여기서 끝나지 않고 앞으로 우리 회원과 교수 등 구 성원들이 보다 적극적으로 국제무대에서 활동할 수 있는 계기 가 되기 위해선 그동안의 제반적인 세계학회 준비 및 운영에 관 한 사항과 성과를 면밀히 검토, 분석해 볼 필요가 있다.

우선 서울 세계소아치과학회의 개요를 보면 다음과 같다.

• 대회 공식명칭: 제 24회 세계소아치과학회 학술대회

The $24^{\text {th }}$ Congress of the International Association of Paediatric Dentistry(IAPD)

\section{Corresponding author : Sangho Lee}

Department of Pediatric Dentistry, School of Dentistry, Chosun university, 375 Seosuk-Dong, Dong-Gu, Gwangju, 501-759, Korea

Tel: +82-62-220-3865 / Fax: +82-62-225-8240 / E-mail: shclee@chosun.ac.kr

Received October 1, 2013 / Revised October 1, 2013 / Accepted October 2, 2013

※ This study was supported by research fund from Chosun University, 2013 and also supported by KAPD. 
- 대회 일자: 2013년 6월 12일(수) 15일(토)

- 대회 장소: 서울 코엑스(그랜드볼룸)

- 대회 주제: New Visions for Paediatric Dentistry

- 주최: 세계소아치과학회 (International Association of Paediatric Dentistry, 이하 IAPD)

- 주관: 대한소아치과학회

- 참가규모: 67 개국 1,885명(전시자, press 포함)

- 학술프로그램: 5개 Pre-Congress Course, 30개 초청강연, 756 편 일반 연제 발표(구연 148 개, 포스터 발표 608개)

- Award: BSBF Award(5명), Jens Andreasen Award (1명), Morita Prize(2명), Travel Bursaries(3명)

- 후원/전시 : 46개 업체 총 64 개 부스 참여

- 사교행사: 개회식, Welcome Reception, Gala Dinner, 폐회식, Farewell Party

- 공식 언어: 영어

•홈페이지: www.iapd2013.org

\section{1. 세계소아치과학회(IAPD) 개요}

세계소아치과학회는 어린이 및 청소년의 구강건강 증진을 위 한 교육 및 홍보활동과 더불어 소아치과 분야의 폭넓은 의견 교 환과 공동 연구를 위해 설립된 국제 학회이다. 44년의 역사를 가진 세계소아치과학회는 1969년 설립 이래 15,000 명 이상의 회원을 보유하고 있다 ${ }^{1}$. 2 년 마다 대륙을 순회하며 개최되는 세 계학술대회에는 약 60 개국 이상의 소아치과 전문의들이 모여 최신 연구 자료를 발표한다.

\section{1) 세계소아치과학회 개최지 선정 과정}

세계소아치과학회는 대회 개최 7년 전 개최 신청서를 IAPD 본부에 제출하고, 6 년 전 IAPD 본부의 개최지 선정위원회 (Congress Site Selection \& Coordinating Committee, 이 하 CSS \& CC)와 임원(board director) 회의를 통해 결정된 다 ${ }^{2.3)}$.

선정 과정은 먼저 유치 제안서의 서면 심사를 통해 일차적으 로 3 4개의 후보국을 선정한 후 이들 후보국들의 현장에서의 구두 $(\mathrm{PPT})$ 발표를 통해 최종 1 개국이 선정된다. 선정된 국가 는 이후 매년(5년간) IAPD 본부에 서면 및 구두 발표를 통해 개최 준비 현황을 보고한달.

\section{2. 조직위원회(이하 “조직위") 구성}

• 2003 2008: 대한소아치과학회 국제이사(이상호 교수)가 유치준비 및 유치과정을 담당하였다.

-2009년 5월: 대한소아치과학회 정기총회에서 조직위원장 (이상호 교수)이 정식으로 위촉되고 이하 조직위가 구성되 어 공식적인 활동을 시작하였다(Table 1).

- 2010년 10월: 국제학회전문용역업체 (PCO)로 Coex convention team이 선정되었다.
Table 1. Local organizing committee of $24^{\text {th }}$ IAPD Congress in 2013

\begin{tabular}{|c|c|c|}
\hline 직위 & 성명 & 소속 \\
\hline 학회장 & 남순현 & 경북대학교 치의학전문대학원 교수 \\
\hline 조직위원장 & 이상호 & 조선대학교 치의학전문대학원 교수 \\
\hline 사무총장 & 이제호 & 연세대학교 치과대학 교수 \\
\hline 사무/총무보 & 이난영 & 조선대학교 치의학전문대학원 교수 \\
\hline 사무/총무보 & 현홍근 & 서울대학교 치의학대학원 교수 \\
\hline 학술위원장 & 박기태 & 성균관대학교 의과대학 삼성서울병원 교수 \\
\hline 학술위원 & 김정욱 & 서울대학교 치의학대학원 교수 \\
\hline 학술위원 & 최성철 & 경희대학교 치의학전문대학원 교수 \\
\hline 학술위원 & 김영재 & 서울대학교 치의학대학원 교수 \\
\hline 학술위원 & 정태성 & 부산대학교 치의학전문대학원 교수 \\
\hline 학술위원 & 전승준 & 분당 예치과 원장 \\
\hline 학술위원 & 김지연 & 부산대학교 치의학전문대학원 교수 \\
\hline 학술위원 & 송제선 & 연세대학교 치과대학 교수 \\
\hline 학술위 고문 & 김 신 & 부산대학교 치의학전문대학원 교수 \\
\hline 기획,재정위원장 & 송민호 & 프린스 \& 프린세스치과의원 원장 \\
\hline 기획,재정위원 & 김재곤 & 전북대학교 치의학전문대학원 교수 \\
\hline 기획,재정위원 & 박재홍 & 경희대학교 치의학전문대학원 교수 \\
\hline 기획,재정위 고문 & 장기택 & 서울대학교 치의학대학원 교수 \\
\hline 사교,진행위원장 & 이재천 & $\mathrm{CDC}$ 어린이치과병원 원장 \\
\hline 사교,진행위원 & 김종수 & 단국대학교 치과대학 교수 \\
\hline 사교,진행위 고문 & 김광철 & 경희대학교 치의학전문대학원 교수 \\
\hline 국제협력위원장 & 최영철 & 경희대학교 치의학전문대학원 교수 \\
\hline 국제협력위원 & 이수전 & UMD 칠드런 치과 원장 \\
\hline 정보통신위원장 & 박호원 & 강릉원주대학교 치과대학 교수 \\
\hline
\end{tabular}

\section{3. 제 24회 세계소아치과학회 유치/개최 추진 경과}

1) 유치 의사 전달(2003. 10. 15 18)

유치의사를 전달하기 위해 대한소아치과학회에서는 2003년 미국 뉴올리언즈에서 개최된 제 19회 세계소아치과학회에 이상 호, 최영철 교수를 파견하여 유치신청 과정에 대한 자료를 확보 하였다. 이후 당시 이상호 국제이사가 유치 신청서를 작성하여 2005년 4월 30일 IAPD 본부에 제출하였다.

2) 유치 확정 (2005. 10. 31 11.5)

호주 시드니에서 개최된 제 20 회 세계소아치과학회에 대한소 아치과학회(회장 김종철)는 유치신청단(김종철, 김신, 이상훈, 최영철, 이상호, 박호원, 이수전)을 파견하여 유치 제안에 대해 탁월한 발표와 활발한 외교를 벌인 결과 2013년 유치가 확정되 었다.

3) 개최 준비 보고 및 대회 홍보

•2007. 6. 13 17

홍콩에서 개최된 제 21회 세계소아치과학회에서 서울 대회를 홍보하였다.

- 2008년도 크로아티아에서 개최된 IAPD board directors meeting에 당시 국제이사인 이상호 교수와 이수전 원장을 파견하여 개최 준비 현황 보고 방법에 대한 정보를 입수하 였다. 
-2009. 6. 17 20

2009년 5월 대한소아치과학회 정기총회에서 이상호 교수가 정식으로 2013년 서울 세계소아치과학회 조직위원장으로 위촉 되고 이하 조직위원들이 구성되었다.

2009년 독일 뮌헨에서 개최된 제 22회 세계소아치과학회에 최병재 학회장, 김신 교수, 이상훈 교수, 이상호 조직위원장 및 박기태, 이재천 위원 등 대표단이 참석하여 한국 개최를 홍보하 고 이수전 원장이 준비 현황을 보고하였다.

-2010. 6. 2 6

영국 헤러게이트에서 개최된 유럽소아치과학회에 이상호 조 직위원장과 이수전 해회협력위원이 참석하여 IAPD board director 회의에서 한국의 준비현황을 보고하였다.

•2011. 6. 15 18

그리스 아테네에서 개최된 제 23차 세계소아치과학회에 대한 소아치과학회(회장 김신)에서는 조직위원들을 파견하여 한국 홍보와 한국의 밤을 개최하였다. 김신 학회장, 백병주 교수, 이 상호 조직위원장, 이제호 사무총장, 장기택 재정위원장, 이재천 사교진행위원장 등 많은 임원과 조직위원들이 참석하여 한국의 밤 행사를 주관하였으며, 이상호 조직위원장, 박기태 학술위원 장, 이수전 해외협력위원이 준비 현황을 보고 하였다.

• 2012. 5. 24 27

프랑스 스트라스부르에서 개최된 제 9회 유럽소아치과학회에 조직위원들이 파견되어 한국 개최를 홍보하였다. 이상호 조직 위원장, 박기태 조직위 학술위원장, 이수전 해외협력위원이 준 비 현황을 보고하였다.

-2012. 5월

- 일본 도쿄에서 개최된 일본소아치과학회 창립 50 주년 기 념 국제학술대회에 남순현 학회장, 이상호 조직위원장, 박기태 학술위원장, 김정욱 교수, 현홍근 교수, 양연미 교수 등 다수의 조직위원들이 참석하여 한국 개최를 홍보 하였다.

- 인도네시아 발리에서 개최된 제 8회 아시아 소아치과학

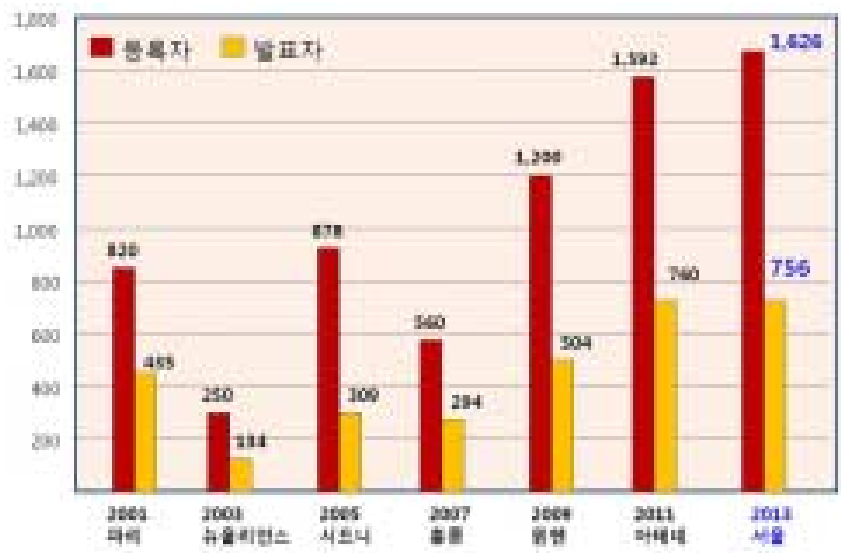

Fig. 1. Number of participants and presentations(oral and poster) in each IAPD congress.
회(PDAA)에 이긍호 선생님, 이제호 교수, 이재천 원장 등이 참석하여 한국 대회 홍보하였다.

- 중국 시안에서 개최된 2013년도 중국소아치과학회에 조직 위원회 사무총장인 이제호 교수가 참석하여 홍보하였다.

- 미국 샌디에고에서 개최된 제 65회 미국소아치과학회 (AAPD)에 국제이사인 김영재 교수, 전승준 원장이 참석 하여 홍보하였다.

\section{II. 대회 주요 결과}

\section{1. 대회 주요 내용 및 결과}

1) 세계대회에 걸맞은 세계 각국의 높은 참석율

IAPD는 유럽 회원이 많아 이들에게 한국은 지리적으로 인접 성이 떨어지고 북한의 위협으로 인해 대외적으로 불안정한 시 기였음에도 불구하고, 아시아뿐 아니라 유럽, 미주, 아프리카에 이르는 67 개국 1,885 명(후원/전시 업체 참가자 포함)의 참가 자들이 대회에 참가하였다. 참신하고 다양한 학술프로그램과 지속적인 한국에 대한 홍보, 저개발 국가 참가자를 위한 등록비 할인 등을 통해 역대 IAPD 대회 중 가장 높은 순수 해외 참가 자 수를 기록하였다 ${ }^{4-8}$ (Fig. 1).

초청 연자와 좌장을 지역별로 배분하여 각 대륙별, 나라별 관 심을 유도하였다(Fig. 2). 한국을 처음 방문하는 외국인들에게 낯선 한국에 대한 거리감을 없애기 위해 한국의 관광 자원들을 이용한 다양한 이미지로 사전에 35차례의 전자메일 (e-blast)을 꾸준히 발송하였다. 페이스북을 통해서는 한국의 일상적인 모 습들을 담아 참가자들에게 자연스럽게 친근감을 높였다. 무엇 보다도 역대 IAPD 대회에서는 시도하지 않았던 '개발도상국가 참가자 등록비 할인 정책'을 통해 대회 참가의 장벽을 많이 낮 추었다. 특히 카자흐스탄, 캄보디아와 같은 개발도상국가의 참 가자들이 100 명 이상 서울 대회에 참여하면서 IAPD 세계 무대 에서 진정한 의미의 참여와 협력의 장을 마련하였다.

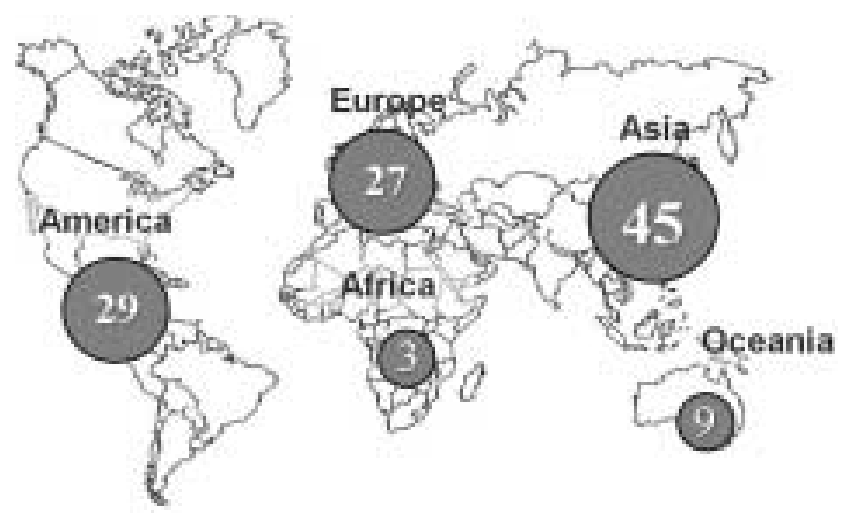

Fig. 2. Distribution of the invited speakers and the chairs of scientific sessions according to the continents. 
2) 다양하고 참신한 학술프로그램 구성

'New Visions in Pediatric Dentistry' 라는 슬로건 아래 치아우식증 진단의 최신 경향 $\boldsymbol{\Lambda}$ 치아우식증 관리의 최신 경향 $\Delta$ 유아기우식증의 관리 $\Delta$ 최신 수복치과재료 $\Delta$ 소아치과분야에 서의 줄기세포에 대한 다양한 기초 연구 및 임상사례 등 참신하 고 최신 이슈가 되는 토픽들로 구성된 총 85개의 초청 강연이 시행되었다. 특히 다른 대회에서 볼 수 없었던, 마지막 날까지 참석자가 외부로 이탈하지 않고 강연장으로 유입될 수 있었던 가장 큰 요인은 85 명의 저명한 초청연자들의 강연이 다양한 테 마들로 짜임새 있게 배치된 데 있었다. 더불어 일반 발표 연제 는 총 755 편 접수되었고, 구연 126편, 포스터 553편이 대회기 간 동안 발표되었다.

3) 한국 문화의 전통과 현재를 느낄 수 있는 사교의 장 마련 대회 기간 동안 4 일 이상 학술 대회장에 머무는 참가자들에 게 한국의 문화를 체험할 수 있는 다양한 기회를 대회장소 곳곳 에 배치하였다. 소아치과 의사로서의 자부심과 사명감을 되새 길 수 있는 공연과 세계 속 현재의 '한류' 를 보여주는 K-Pop 공연 등을 통해 공감하고 참여하는 사교행사를 유도할 수 있었 다. 특히 행사장 곳곳에서 쉽게 한국의 문화를 접할 수 있도록 유도하여 행사장에 활기를 불어넣었다. 전시장 안에는 소아치 과의 역사를 볼 수 있는 책들이 전시되었고, 세계 각국에서 수 집한 치과 관련 인형들이 소개되었다. 한국의 전통 물건들을 기 념품으로 구매할 수 있는 코너가 마련되었고, 전통 궁중의상을 입어보고 사진을 찍을 수 있는 이벤트는 외국인들의 호응이 매 우 높았다. Welcome Reception에는 800명이 넘는 인원이 참 석하여 오디토리움을 꽉 채웠고, gala dinner는 250 명의 정원 을 초과하여 337명이 참석을 하였으며, farewell party 또한 사전 예상한 인원을 50 명 이상 초과하는 213 명이 참석하였다. 야외에서 자유롭게 진행된 gala dinner와 farewell party를 통 해 참가자들이 좀 더 편안한 분위기에서 쉽게 교류할 수 있는 기회가 제공되어 참가자들의 만족도가 높았다.

\section{2. 전망 및 기대효과}

IAPD 2013 Seoul 대회를 통해 참가한 67개국 1,885명의 참가자들에게 한국 소아치과학의 위상을 알리고, 국내 소아치 과의 치과의료 수준이 국제적임을 인정을 받았다. 아울러 기존 치료법에 대한 새로운 관점을 제시하고, 줄기세포, 유전, 최신 수복재료 등 미래 소아치과학의 새로운 비전을 제시하였다.

국내 젊은 의사들의 국제 무대를 향한 발판을 마련했다는 데 에도 큰 의의가 있다. 국제 학술대회 경험이 많지 않은 국내의 젊은 대학원생, 전공의의들이 논문 게재뿐 아니라 각종 행사를 통해 인적 교류의 기회를 넓히고 국제 무대로 진출할 수 있는 길을 넓혔다.

또한 유럽을 중심으로 움직이던 세계 소아치과계가 한국, 그 리고 아시아가 주도적 역할을 할 수 있는 도약의 계기가 되었 다. 대회 기간 동안 열린 공식/비공식 미팅 $\mathbf{\Delta}$ 대한소아치과학회
와 일본소아치과학회의 $\mathrm{MOU}$ 체결식 $\mathbf{\Lambda}$ 아시아소아치과학회 이 사회 $\Delta$ IAPD Council Meeting $\Delta$ Global Interaction Meeting 등을 통해 호스트 국가로서 주도적 역할을 하며 세계 무대에서 한국의 위치를 각인시킬 수 있었다. 치과계에서는 처 음으로 유치한 세계대회를 성공적으로 치루면서 한국 치과계에 도 좋은 경험의 자산이자 롤 모델이 될 것이다.

\section{3. 분야별 결과 요약}

1) 등록

(1) 등록자 및 참석자 통계

사전등록자는 1,616 명 이였으나 북한의 미사일 발사 위볍 소 식이 전 세계적으로 보도되면서 등록 취소가 잇달아 실제로 사 전에 등록을 완료한 사람은 1,561 명이였다. 그러나 현장등록이 65 명으로 예상보다 많았다. 총 등록자는 1,626 명이였다

(2) 참석자 등록 카테고리별 통계

등록자의 카테고리별 분포는 다음과 같다(Table 2).

(3) 국가별 참석자 통계

일본이 173 명으로 가장 많았으며 중국이 70 명, 대만 39 명, 태국 32 명, 홍콩 29 명, 필리핀 27명, 말레이시아 23명 등 아시 아권 국가의 참석자가 많았다. 미국과 호주도 다른 역대 IAPD 대회보다 참석자가 많았다. 남미권 국가와 스웨덴, 핀란드, 나 이지리아 등 먼 거리에 위치한 국가의 참석자가 많았다. 그러나 프랑스, 이탈리아, 스페인 등 최근 경제 문제가 이슈간 된 유럽 국가들의 참석은 저조하였다(Table 3).

(3) 대륙별 참석자 통계(Fig. 3)

2) 학술

(1) 초록접수

초록접수는 구연이 159 건, 포스터가 596건 총 755 건 이였으 나, 심사를 거쳐 탈락 건이 있었다. 학술대회 진행을 원활하기 위해 조직위가 발표 방법을 조정하여 구연은 126 건, 포스터는 553건 등 총 679편이 발표되었다.

(2) 초청강연 연자

2 개의 기조 강연에 4 명, 10 개의 일반 강연에 26 명, 6 개 심포 지움에 21명 등 총 85 명의 연자를 초청하였다(Table 4).

(3) 좌장

초청 강연 좌장 44 명, 일반 연제발표 좌장은 구연의 경우 40 명, 포스터 발표가 72 명이였다. 초청강연 죄장과 일반 연제 죄 장은 중복된 경우도 있다. 
Table 2. Participants according to registration category

\begin{tabular}{|c|c|c|c|c|}
\hline \multirow{2}{*}{ 구분 } & \multicolumn{2}{|c|}{ 국내 } & \multicolumn{2}{|c|}{ 국외 } \\
\hline & 사전등록 & 현장등록 & 사전등록 & 현장등록 \\
\hline IAPD 회원 & 426 명 & 0 명 & 241 명 & 10 명 \\
\hline IAPD 회원(그룹A) & 0 명 & 0 명 & 46 명 & 10 명 \\
\hline IAPD 회원(그룹B) & 0 명 & 0 명 & 7 명 & 0 명 \\
\hline IAPD 비회원 & 0 명 & 0 명 & 228 명 & 10 명 \\
\hline IAPD 비회원(그룹A) & 0 명 & 0 명 & 22 명 & 0 명 \\
\hline 수련의/대학원생 & 162 명 & 0 명 & 155 명 & 2 명 \\
\hline 치위생사 & 7 명 & 3 명 & 31 명 & 5 명 \\
\hline 학부생 & 0 명 & 0 명 & 19 명 & 0 명 \\
\hline Honorary/Senior 멤버 & 0 명 & 0 명 & 9 명 & 1 명 \\
\hline 동반자 & 2 명 & 6 명 & 83 명 & 7 명 \\
\hline 전시장 단순방문 & 0 명 & 6 명 & 0 명 & 10 명 \\
\hline 기타 & 0 명 & 4 명 & 0 명 & 1 명 \\
\hline 초청연사 & 12 명 & 0 명 & 75 명 & 0 명 \\
\hline 좌장 & 10 명 & 0 명 & 16 명 & 0 명 \\
\hline 소계 & 638 명 & & 988명 & \\
\hline 학술참가자 총계 & 1,626 명 & & & \\
\hline 전시관계자 & 215 명 & & & \\
\hline 기자 & 8 명 & & & \\
\hline 스탭 & 30 명 & & & \\
\hline 기타 관계자 총계 & 253명 & & & \\
\hline 참가자 총계 & 1,879명 & & & \\
\hline
\end{tabular}

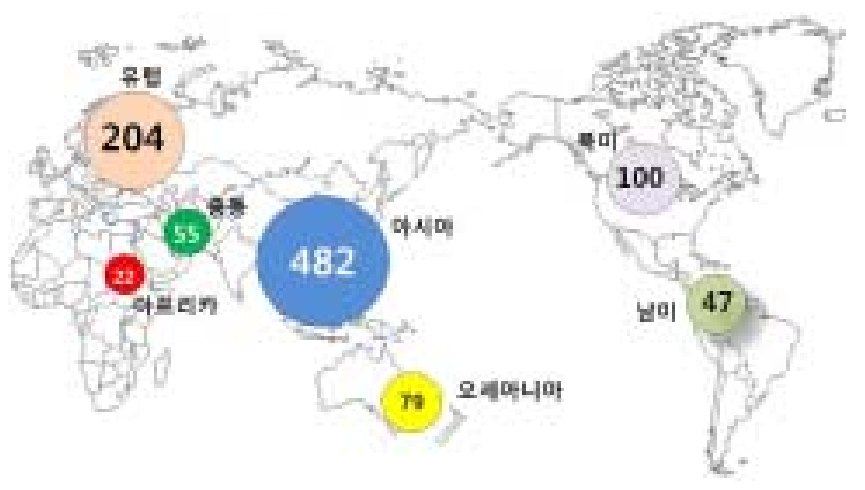

Fig. 3. Distribution of the participants according to the continent.

3) 후원/전시

(1) 개요

- 전시 기간: 2013년 6월 13일(목) 15일(토)

- 전시 부스: 총 64 개 부스 전시(14개 독립부스, 50 개 기본 부스)

- 전시장: 코엑스 1 층 $\mathrm{B} 2$ 홀 $\left(3,645 \mathrm{~m}^{2}\right)$

(2) 후원 업체

5,000 만원 이상의 골드 스폰서는 $3 \mathrm{M} \mathrm{ESPE} \mathrm{사,} \mathrm{3,000만원}$ 이상의 실버 스폰서는 (주) 신흥, (주) 보령, GC Korea 등 3개 사, 2,000 만원 이상의 브론즈 스폰서는 5 개사, 그리고 1,000
Table 3. Distribution of the participants according to the nations

\begin{tabular}{|c|c|c|c|c|c|}
\hline No & 국가명 & 참가자 & No & 국가명 & 참가자 \\
\hline 1 & 대한민국 & 637 & 34 & 네덜란드 & 7 \\
\hline 2 & 일본 & 173 & 35 & 캄보디아 & 6 \\
\hline 3 & 미국 & 84 & 36 & 그리스 & 6 \\
\hline 4 & 중국 & 70 & 37 & 페루 & 5 \\
\hline 5 & 호주 & 65 & 38 & 프랑스 & 3 \\
\hline 6 & 영국 & 45 & 39 & 수리남 & 3 \\
\hline 7 & 대만 & 39 & 40 & 아르헨티나 & 2 \\
\hline 8 & 인도네시아 & 32 & 41 & 벨라루스 & 2 \\
\hline 9 & 태국 & 32 & 42 & 부르나이 & 2 \\
\hline 10 & 홍콩 & 29 & 43 & 스페인 & 2 \\
\hline 11 & 필리핀 & 27 & 44 & 이란 & 2 \\
\hline 12 & 사우디아라비아 & 27 & 45 & 레바논 & 2 \\
\hline 13 & 인도 & 26 & 46 & 몽골리아 & 2 \\
\hline 14 & 터키 & 26 & 47 & 폴란드 & 2 \\
\hline 15 & 말레이시아 & 23 & 48 & 포르투갈 & 2 \\
\hline 16 & 벨기에 & 20 & 49 & 루마니아 & 2 \\
\hline 17 & 러시아 & 19 & 50 & 베트남 & 2 \\
\hline 18 & 싱가포르 & 17 & 51 & 콜롬비아 & 1 \\
\hline 19 & 캐나다 & 16 & 52 & 에콰도르 & 1 \\
\hline 20 & 스웨덴 & 15 & 53 & 과테말라 & 1 \\
\hline 21 & 브라질 & 13 & 54 & 아일랜드 & 1 \\
\hline 22 & 멕시코 & 13 & 55 & 이탈리아 & 1 \\
\hline 23 & 핀란드 & 12 & 56 & 카자흐스탄 & 1 \\
\hline 24 & 나이지리아 & 12 & 57 & 쿠웨이트 & 1 \\
\hline 25 & 뉴질랜드 & 12 & 58 & 라오스 & 1 \\
\hline 26 & 독일 & 11 & 59 & 리비아 & 1 \\
\hline 27 & 덴마크 & 11 & 60 & 리히텐슈타인 & 1 \\
\hline 28 & 이스라엘 & 11 & 61 & 라트비아 & 1 \\
\hline 29 & 아랍에미리트 & 10 & 62 & 오만 & 1 \\
\hline 30 & 이집트 & 8 & 63 & 카타르 & 1 \\
\hline 31 & 노르웨이 & 8 & 64 & 통가 & 1 \\
\hline 32 & 스위스 & 7 & 65 & 베네수엘라 & 1 \\
\hline \multirow[t]{2}{*}{33} & 칠레 & 7 & 66 & 바누아투 & 1 \\
\hline & & & 67 & 앙골라 & 1 \\
\hline \multicolumn{6}{|c|}{67 개국 1,626 명 } \\
\hline
\end{tabular}

만원 이상의 아이언 스폰서는 3개사 였으며, 단품 후원사 및 특 별 후원사를 포함하여 총 20개사가 후원하였다(Table 5).

\section{(3) 후원 기관}

서울관광마케팅에서 3,600만원, 한국관광공사가 2,100만원, 강남구청이 300 만원을 지원하였다. 대한치과의사협회, 대한치 의학회, 공직치과의사회 등 치과계 관련 단체로 부터는, 세계소 아치과학회가 우리나라 치과계의 위상을 높일 수 있는 국제적 인 치과 행사임에도 불구하고, 아무런 지원을 받지 못하였다. 향후 우리 치과계가 재고해야 할 부분으로 생각된다. 
Table 4. Distribution of the invited speakers according to the types of lectures and topics

\begin{tabular}{|c|c|c|}
\hline 구분 & 토픽 & 연자 수 \\
\hline Keynote Lecture (2) & New dental Apps in caries prevention & 2 \\
\hline \multirow{12}{*}{$\begin{array}{c}\text { Lectures } \\
\text { (10) }\end{array}$} & New horizons and challenges in Paediatric dental sedation & 3 \\
\hline & Minimal-invasive dentistry & 2 \\
\hline & Dental materials I & 2 \\
\hline & Genetic perspectives in pediatric dentistry & 3 \\
\hline & Dental trauma & 3 \\
\hline & "Special smiles I" & 3 \\
\hline & Dental care for special children & \\
\hline & Dental materials II & 2 \\
\hline & Limits and borders of laser use in children & 2 \\
\hline & Pulp & 3 \\
\hline & Dental impaction & 2 \\
\hline & Early orthodontic treatment & 4 \\
\hline Symposium & Early caries detection & 3 \\
\hline \multirow[t]{6}{*}{ (6) } & Dental erosions in children & 4 \\
\hline & "Special smiles II" & 3 \\
\hline & Dental care systems for patients with special needs & \\
\hline & Dental stem cells for regenerative dentistry & 3 \\
\hline & Early childhood caries & 3 \\
\hline & Dental education "HOW TO BECOME A PEDIATRIC DENTIST" & 5 \\
\hline \multirow[t]{5}{*}{ Others } & Clinical practice: What's New? & 15 \\
\hline & "Treasure Island": My strategy in private practice & 10 \\
\hline & Lunch \& Learn & 3 \\
\hline & Pre-congress course & 5 \\
\hline & Total & 85 \\
\hline
\end{tabular}

Table 5. Sponsors(companies) for 2013 Seoul IAPD Congress

\begin{tabular}{cl}
\hline 후원 등급 & \multicolumn{1}{c}{ 업체 명 } \\
\hline 골드 & $3 \mathrm{M} \mathrm{ESPE}$ \\
실버 & (주) 신흥 \\
& (주) 보령 \\
& GC Korea co., Ltd. \\
& NuSmile Pediatric Crowns \\
& DMG Dental Material GmbH \\
브론즈 & SHOFU INC. \\
& Bisco \\
& Inspektor Asia \\
& IvoclarVivadent AG \\
& 오스템 \\
& 미르치과그룹 \\
& Cheng Crowns \\
아이언 & Porter Instrument/Matrx by Parker \\
& Morita \\
단품 후원 & 애경 \\
& 시로나 \\
& 거산기공소 \\
& 현대 자동차 \\
& 대한항공 \\
&
\end{tabular}

(4) 협찬 업체

협찬 업체의 섭외는 주로 개인적으로 이루어졌으며 현금 지 원은 아니였으나 현금 지원 못지않게 대회 운영에 실질적으로 많은 도움이 되었다.

“가비양” 에서 커피 3천 잔을 제공하였으며 “카페베네”에서는 council meeting에 커피와 다과 80인 분을 제공하였다. "국순 당” 에서는 welcome reception에 백세주 100병을 제공하였다. “화요” 역시 welcome Reception에서 시음 행사를 하였으며, “롯데아이시스" 는 생수 1,000 병 무료로 제공하였다.

(5) 전시 업체

후원사에게는 등급에 따라 무료로 전시 부스가 제공되었으며 일반 전시업체를 포함하여 총 46 개사의 64 개 부스가 설치되었 다(Table 6).

(6) 기타 전시

대한소아치과학회 광주.전남지부 권훈 지부장이 1742년부터 현재까지 발간된 소아치과 관련 교과서 120 여점을, 서울대학 교 치의학대학원 소아치과학교실 장기택 교수의 부인인 치과의 사 민선경 원장이 치과와 관련된 전 세게 인형 200 여점을 제공 하여 특별 전시회를 개최하였다. 
Table 6. Companies and organizations participated in the exhibition of 2013 IAPD congress

\begin{tabular}{|c|c|c|}
\hline No & 업체 명 & 부스 갯수 \\
\hline 1 & 3M ESPE & 4 \\
\hline 2 & Bisco & 2 \\
\hline 3 & (주) 보령 & 3 \\
\hline 4 & Cheng Crowns & 1 \\
\hline 5 & 조광데탈 & 1 \\
\hline 6 & DENTALL & 1 \\
\hline 7 & Dentos, Inc & 1 \\
\hline 8 & DENTSPLY KOREA & 1 \\
\hline 9 & DMG Dental Material GmbH & 2 \\
\hline 10 & EDEN Co. & 1 \\
\hline 11 & GARAM Orthodontics Dental Laboratory & 1 \\
\hline 12 & GC Korea co., Ltd. & 3 \\
\hline 13 & Global Dental Relief & 1 \\
\hline 14 & Global Microscope Korea & 1 \\
\hline 15 & HDX Corporation & 1 \\
\hline 16 & 현대자동차 & 2 \\
\hline 17 & IAPD - International Association of Paediatric Dentistry & ry 1 \\
\hline 18 & IAPD 2015 & 1 \\
\hline 19 & Inspektor Asia & 2 \\
\hline 20 & IvoclarVivadent AG & 2 \\
\hline 21 & KOMET DMI KOREA Co., Ltd & 1 \\
\hline 22 & (주)광명 & \\
\hline 23 & META BIOMED & 1 \\
\hline 24 & 미동양핼 & 1 \\
\hline 25 & Morpheus Co., Ltd. & 1 \\
\hline 26 & 나래출판사 & 1 \\
\hline 27 & NIBEC CO.,LTD. & 1 \\
\hline 28 & NuSmile Pediatric Crowns & 2 \\
\hline 29 & ORTHOLUTION CO., LTD. & 1 \\
\hline 30 & Ossco (BioMTA) & 1 \\
\hline 31 & (주) 오스템 & 1 \\
\hline 32 & OSUNG MND CO., LTD & 1 \\
\hline 33 & PDAA & 1 \\
\hline 34 & Porter Instrument / Matrx by Parker & 2 \\
\hline 35 & Ray. Co., Ltd & 1 \\
\hline 36 & ROI VISUAL CO., LTD & 1 \\
\hline 37 & Seoul Children's Dental Center & 1 \\
\hline 38 & Seoul Kidspapa Dental Clinic & 1 \\
\hline 39 & (주) 신흥 & 3 \\
\hline 40 & SHOFU INC. & 2 \\
\hline 41 & The Korean Academy of Pediatric Dentistry (KAPD) & 1 \\
\hline 42 & THEZONWORLD CO., LTD & 1 \\
\hline 43 & VATECH Networks & 1 \\
\hline 44 & VERICOM & 1 \\
\hline 45 & Xenosys & 2 \\
\hline 46 & Yours Dental Co., Ltd. & 1 \\
\hline \multicolumn{2}{|r|}{ 합계 } & 64개 \\
\hline
\end{tabular}

\section{4. 평가 및 개선 사항}

1) 등록 및 홍보

(1) 준비과정 평가

- 해외 참가자 관리

조직위에서는 해외참가자들의 등록을 유도하기 위해 학술프 로그램 뿐 아니라 한국의 다양한 문화와 관광자원을 홍보자료 로 활용하고자 하였고, 다양한 시각적 이미지를 활용한 e-blast 와 페이스북 홍보가 해외 참가자들의 등록 유도에 큰 도움이 되 었다. 특히 정치적으로 불안정한 시기에 조직위원장이 직접 쓴 뉴스레터 서신은 등록자 이탈을 막는 결정적인 계기가 되었다.

1 차 사전 등록이 마감(3월 31일)되기 한달 전부터 등록과 관 련한 이메일 문의가 매우 많아졌다. 국내 참가자와 국외 참가자 관리를 이원화하여, 문의에 대한 신속한 응대가 가능하도록 하 였고, 정기적으로 발송하는 e-blast에 가장 문의가 많은 사항들 에 대한 reminder 안내를 하였다. 1,000명 규모의 해외 참가 자가 참석할 경우 VISA 발급을 위한 invitation letter에 대한 요청이 많기 때문에, 사전에 등록 시스템 구축시 마이페이지에 서 invitation letter를 직접 다운 받을 수 있게 한 점이 참가자 관리에 매우 용이하였다.

\section{- 국내 참가자 관리}

국내 참가자 관리는 커뮤니케이션 창구를 $\mathrm{PCO}$ 와 대한소아 치과학회 양쪽에 열어두어, 국내 참가자에 친숙한 학회 사무국 의 역할이 컸다. 국내 참가자는 대한소아치과학회 홈페이지를 통해 국내 등록페이지로 연결되도록 하여 해외 참가자의 등록 시스템과는 별도 운영을 하였다. 국내 참가자 대부분이 소아치 과학회 회원이었고, 각 대학병원 소아치과 과장을 중심으로 그 룹 등록을 장려하여 편의를 제공하였다.

학생들에게도 참관 기회를 주기 위해 12 일 Pre-congress 코 스 참관 등록을 허용하였다.

- 온라인 등록 시스템

사전 온라인 등록 과정에서 홈페이지의 기술적인 오류가 잦 아 참가자들은 이메일로 문의를 다시 해야 하고, 관리자는 수동 으로 업무를 처리해야 하는 번거로움이 많았다. 특히 해외 참가 자들이 온라인으로 결제하는 시스템이 익숙하지 않고, 윈도우 사양 등에 따라 온라인 카드 결제 프로그램 설치에 오류가 나는 경우도 있어, 수동으로 카드 수기 결제를 해야 하는 사례가 많 았다. 자동으로 발송되는 이메일의 경우에는 부득이하게 대회 이메일 주소가 기관/학교의 스팸 이메일로 등록이 되기도 하여 등록확인 이메일 수신율이 낮아 e-blast를 통해 여러 번 마이페 이지에서 직접 확인을 하도록 유도해야했다.

조직위에서 참가자 배려를 위해 '원스탑 플랫폼' 을 제공하고 자 등록과 초록제출, 숙박/관광 예약을 하나의 통합아이디로 예 약/확인까지 가능한 시스템을 구축하였다. 이를 통해 초록발표 자가 직접 등록을 할 수 있도록 유도하기 용이했고, 참가자도 로그인만 하면 마이페이지에서 초록제출현황과 등록현황 등을 한번에 파악 가능했다. 


\section{(2) 사후 평가}

높은 사전등록률을 고려하여 현장에서 바코드시스템을 통해 네임택을 발급함으로써 배부 시간을 최소화하여 대기 시간을 줄일 수 있었다. 특히 해외참가자 대부분은 바코드 등록확인증 을 들고 와서 이름 철자를 확인하는 과정에서 소요되는 대기 시 간이 많이 줄어들 수 있었다. 등록데스크가 세션룸 가까이 위치 해 있어, 위치/교통/관광/대회안내 등의 다양한 문의를 한곳에 서 처리하기 용이했고, 언어별 특이자(일본어, 중국어, 영어)를 등록데스크에 다수 배치하여, 참가자 편의 제공에 수월했다.

등록데스크가 오픈한 12 일에는 아직 시스템과 대회 정보가 충분하지 않은 운영 요원의 운영이 미숙한 부분이 있었다.

(3) 개선 사항

- 온라인 등록 관리

자동 발송 이메일 수신율을 높이기 위해서는 해외에서 대회 이메일이 스팸메일로 처리되는 건들을 확인하여 시일이 걸리더 라도 해당 해외 기관/학교에 스팸 해지 요청을 건건이 진행하는 것이 필요하다.

\section{- 홈페이지 관리}

홈페이지 업체의 운영 미숙 또는 시스템의 오류 등으로 홈페 이지에 소요되는 인력과 시간의 낭비가 많았던 만큼 추후 업체 선정 시 신중한 판단이 필요하다. (해외 참가자용 결제프로그램, 의학학술대회 프로그래밍 운영경험 등)

- 현장 등록데스크 운영

현장 운영이 미숙한 운영요원에게 시뮬레이션 교육 사전 진행 이 필요하다. $(1,2$ 차 사전교육은 진행했으나, 디테일하고 다양한 케이스들을 실제 응대해보는 시뮬레이션 교육이 부족했음.)

\section{2) 학술}

(1) 준비과정 평가

- 연자/좌장 관리

초기 연자 초청과정은 학술위원회에서 진행하였고, $\mathrm{PCO}$ 에 서는 사전 참석을 확정한 연자들에게 공식 서신을 발송한 2012 년 8월부터 본격적인 연자 섭외 업무가 시작되었다. 여러 차례 의 가이드라인이 발송이 되었으나, 연자들이 등록이나 호텔예 약을 직접 해야 함에도 불구하고 사무국에서 진행하는 것으로 착각하고 마감일에 가까워질 때까지 등록률이나 호텔 예약률이 낮았다. 온라인 등록 시스템이 연자용으로 따로 구축되어 있지 않았기 때문에, 등록비 변경 확인을 위해 연자들이 한번 더 로 그인 해야 하는 시스템이 번거로웠다.

연자들에게 교통편의를 제공하기 위해 공항리무진 버스티켓 을 공항 IAPD 안내데스크에서 제공하였다. 연자들은 공항 데 스크에서 대회 staff가 직접 교통 안내를 해주는 것에 대해 매우 만족해 하였다.

또한 학술위원회에서 세션별 연자 이메일을 공유하고 초록 등을 연자/좌장과 미리 공유하여 사전에 연자와 좌장에게 세션 에 대한 정보를 최대한 많이 제공할 수 있었고 현장에서 활발한 토론 및 참여로 이어질 수 있었다.

\section{•초록 제출 관리}

초록 제출/심사결과/발표일정등과 관련된 모든 업무는 마이 페이지에서 확인 가능하도록 함에도 불구하고 낮은 이메일 수 신율 때문에 초록 심사 결과와 관련된 문의가 많았다. 1 인 1 개 의 초록 발표라는 IAPD 본부의 정책에 따르면서 이중 초록 제 출자들의 누락이 많이 생겼고, 대체 발표자를 유도해서 등록시 키는 과정까지 케이스별로 변동사항이 많아 최종발표자/발표 초록 확정까지 시간과 인력이 많이 소요되었다.

본부에서 또한 1 인 1 개의 초록 발표에 대한 아주 명확한 가 이드라인이 없어서 (award 초록의 경우 1 인 2 개의 초록 발표를 허용했음) 혼선이 있었다.

학술위원회에서는 구연/포스터 발표와 관련 최대한 상세 정 보를 가이드라인으로 만들고자 하였고, 홈페이지에서 공유함으 로써 사전 혼선을 막고 발표자들이 쉽게 정보에 접근할 수 있었다.

- 홈페이지 관리

학술 프로그램이 변동되거나 연자 정보가 업데이트될 때 오 탈자나 정보 누락 등으로 초기 홈페이지 관리가 미흡했다. 학술 프로그램의 변동이 많은 점은 예상 가능한 부분인데 홈페이지 의 업데이트 속도나 정확도가 많이 떨어져서 혼선이 있었다.

- Award 관리

Award 운영은 IAPD 본부에서 운영하는 것이 원칙이고, 신 청도 본부에서 받았으나, 본부의 요청에 따라 신청자에 대한 정 보를 수집하고 award도 홍보하기 위해 award를 위한 초록제 출 시 확인을 하고 신청서를 본부에 낼 수 있도록 안내했다. 초 록 제출 마감 후 상당수의 참가자들이 신청서 제출 없이 체크 박스 표시를 award 신청으로 착각하여 본부와 cross 체크하는 과정이 불필요하게 소요되었다. 사전 award 심사를 위해 사무 국에서 award 심사용 PDF 파일을 취합하여 전달함으로써 본 부의 심사과정이 매우 편리했다.

\section{(2) 사후 평가}

- 학술장 관리

현장에서 연자들에게 다시 한번 제공된 가이드라인 등을 통 해 연자들의 프리뷰룸 활용도가 매우 높았고, 지정된 시간보다 일찍 와서 세션룸을 체크하는 연자들이 많았다. Mac과 개인 노 트북을 사용하는 연자들이 꽤 많았지만, 룸별로 테크니션 1명/ 운영요원 2 명이 한 조로 업무를 분담하면서 업무 효율이 높았 다. 좌장이나 연자의 현장 부재(no-Show)나 발표자료 누락을 막기 위한 사전 프리뷰 룸/등록데스크와의 원활한 커뮤니케이 션이 현장 운영에 큰 도움이 되었다. 또한 학술위원회에서 사전 에 배정한 세션룸별/일자별 담당 학술위원들의 역할로 현장 운 영시 미흡한 점들이나 의사 결정이 필요한 사항들에 대해 빨리 조치할 수 있었다.

13 일 기조강연 때 실시간 온라인 토론 및 무선 와이파이에 대한 안내가 좀 더 일찍 다양한 방법으로 안내되지 못해 홍보가 미흡했다.

\section{- 포스터 발표 관리}

포스터 발표장에 기본 운영요원 2 인이 배치되었으나, 워낙 
포스터의 양이 많고, 매일 부착/탈착이 반복되다 보니 현장에서 안내 인력이 더 많이 필요했다. 기존에 준비한 준비물품(칼, 가 위, 테이프)도 분실이 많아 현장 필요 물품이 많이 발생했고, 본 인 포스터의 부착 장소를 착각한 참가자 때문에 다른 참가자의 포스터가 분실되기도 하였다.

\section{(3) 개선 사항}

- 연자/좌장 관리

연자/좌장의 등록비 면제가 차별적으로 해당하고, 등록비 면 제에 대해 공식적으로 오픈하고자 하지 않았기 때문에 등록페 이지를 따로 구축하지 않았으나, 등록페이지의 별도 구축이 필 요하다. 특히 연자 등록이 자발적으로 잘 이루어 지지 않는 경 우에는 연자 등록페이지를 별도로 구축하여 등록비 셋팅 $\left(\mathrm{com}^{-}\right.$ plimentary)을 별도로 하여 연자에게 편의 제공이 필요하였다.

초기에 초록 제출 마감시기를 결정할 때 초청 연자들의 초록 제출 마감일을 일반 초록과 동일하게 설정할 필요가 없다. 초청 초록은 프로그램북 제작시기에 맞춰 여유 있게 마감일을 설정 하였으면 연자들의 부담감도 덜 수 있고, 초청과 일반 초록을 명확하게 구분하기 용이하다.

- 포스터 발표 관리

포스터의 탈부착이 매일 아침/저녁으로 있을 시에는 관리 인 력이 2 배 이상 배치될 필요가 있다. 특히 아침에 당일 붙여져야 할 포스터의 제목/발표자 이름이 기재된 $\mathrm{A} 4$ 안내문이 각 포스 터 보드에 붙여져서, 발표자가 한번 본인의 포스터보드를 확인 할 수 있게 하고, 당일 저녁에 미탈착된 포스터들은 일괄적으로 탈착하는 관리가 필요하다.

- Award 관리

Award를 위한 초록 제출과 일반 초록 제출을 일원화 하여 온라인으로 접수할 수 있다면 본부와 cross 체크하는 과정을 줄 이고, 참가자 편의도 증대할 수 있을 것으로 기대된다.

- 홈페이지 관리

연자 CV나 사진을 따로 받지 않고, 홈페이지에서 초록 제출 과 동시에 모두 같은 틀 안에서 입력하는 시스템으로 운영할 경 우 형태의 통일성과 자동 업데이트의 신속함은 더 높았을 것으 로 예상된다.

홈페이지 업데이트와 모바일페이지 업데이트가 연동이 되지 않기때문에 동시 업데이트 및 확인이 불가능한 단점을 해결하 기 위해서는 홈페이지 구축 초기 단계에서 시스템 연동을 위한 방안 모색이 필요하다.

- 보수교육 점수

국제적으로 저명한 초청강연이 80 건 이상에 4 일간 개최된 세 계학회임에도 불구하고 대한치과의사협회로부터 받은 보수교육 인준 점수는 4점이였다.

대한치과의사협회에서는 지역별 기자재전시 및 학술대회 (예:SIDEX, GAMEX, YESDEX, HODX 등)는 단 이틀 동안 만 개최됨에도 불구하고 6점의 보수교육 점수를 주고 있어, 형 평성에 문제가 있음은 물론 각 분과학회에서 개최한 세계적인 학회를, 개원가들이 중심이 된 지역, 지부학술대회보다 대회의
격을 한 수 아래로 보고 있는 치과계의 좁은 인식이 개선될 필 요가 있다고 사료된다.

앞으로 각 분과학회에서 유치한 몇몇 국제학술대회가 준비중 에 있는 만큼 우리 치과계는 이들 국제학회를 통하여 한국의 치 과계와 치과의사들에 대한 위상을 대거 높인다는 점을 충분히 인식하여, 대국적인 차원의 지원과 성원을 보내줄 필요가 있다 고 판단된다.

3) 후원/전시

(1) 준비과정 평가

- 후원/전시 업체 섭외

초반에 세계 학술대회 기준으로 다소 높게 책정 된 부스비로 인해 국내 전시 업체 섭외에 어려움이 있었으나 조직위원회를 비롯한 대한소아치과학회 임원 등 다각도에서의 조직적인 전략 으로 개인적인 체널을 통해 업체 섭외를 시도한 결과 20여개의 후원사를 포함한 총 64 개 부스를 유치할 수 있었다.

특히 조직위에서는 매주 업체 접촉 현황을 공유하며 가능성 있는 업체들의 인적 체널을 확보하였다. 후원 업체는 일대일, 일대다, 학회 차원의 미팅으로 범위를 확대하여 협조를 구했고, 전시업체는 소아치과와 직접적인 관련이 없더라도 마케팅 효과 로 win-win 할 수 있는 업체들은 주변 인맥을 통해 참여를 요 청하였다.

해외에 본사를 두고 있는 주요 후원업체를 섭외하는 과정에 서는 조직위의 노력들이 여러 상황들로 제약을 받았고, 이로 인 해 다음과 같은 IAPD 전차 대회의 주요 후원사였던 해외 업체 들의 참여가 없었던 점이 아쉬웠다.

- 후원/전시 업체 관리

전시 업체들은 사무국을 통해 일원화된 루트로 통관/수송, 전 시 부스 설치, 비품 신청까지 전시자 매뉴얼을 통해 접수/관리 되었다. 국내 전시 업체들의 경우 매뉴얼에 의존하기 보다는 사 무국에 직접 문의하는 경우가 많았으나, 대부분 기본 부스를 이 용했기 때문에, 부스 위치 배정 이외에는 특별한 요구 또는 불 만 사항이 없었다.

- 협찬 및 후원기관 협조 요청

조직위원회에서는 보건복지부, 대한치과의사협회, 치의학회 등의 관련 기관의 후원을 위해 고위층과의 면담, 제안서 서면 제출 등 다양한 방법을 통해 접촉했으나, 기관 명칭 사용에 대 한 허가는 가능하지만 실질적인 현금 후원은 전례가 없었다는 등의 이유로 불가능했다.

반면 지출을 줄이기 위해 조직위원회와 사무국이 적극 노력 한 결과 좋은 성과를 낼 수 있었다. 사무국에서는 커피 브레이 크에 소요되는 비용 약 1천만원에 해당하는 커피 협찬을 추진 하였고, farewell 파티 만찬주인 백세주와 welcome reception 시음주인 화요 협찬을 통해 식음료 비용을 절감할 수 있었다. 또한 대한항공과의 협약을 통해 Korean Air의 항공권 할인율 을 기존 MICE 할인율 $(10 \%)$ 보다 높은 $20 \%$ 까지 받아, 참가 자 뿐 아니라 조직위의 연자 항공권 구매시에도 혜택을 받을 수 있었다. 
또한 서울시장 초청을 위한 조직위원회의 적극적인 노력과, 사무국의 제안으로 서울관광마케팅과 한국관광공사에서 기존에 예상했던 예산보다 약 $80 \%$ 이상 증대한 수입을 확보할 수 있 었다.

\section{(2) 사후 평가}

스페셜 전시와 이벤트존의 구성으로 학술대회 참가자들의 전 시장 방문이 효과적으로 유도되었다. 특히 한복체험 존과 기념 티셔츠 이벤트 부스는 해외 참가자들에게 큰 인기가 있었으며 예상보다 인원이 많이 몰린 까닭에 인력을 추가로 배치하여 참 가자들을 안내하였다. 또한 소아치과 학술대회를 위해 특별히 조성된 책 전시와 인형전시는 참가자들에게 다양한 볼거리를 제공하였다.

전시장 안쪽에 위치한 커피스테이션과 휴식공간이 넓게 확보 된 점과 동시에 인접하는 포스터 세션 및 전시업체들과의 동선 이 짧아 참가자들의 편의를 도모할 수 있었다.

자사에서 다양한 홍보를 준비해 왔던 업체들의 만족도가 상 대적으로 높았으며 특히 해외 참가업체들의 만족도는 기대 이 상이었다.

\section{(3) 개선 사항}

독립 부스 설치 시 $5 \mathrm{M}$ 높이에 대한 제한 규정은 있었으나, 실제 설치된 독립 업체들의 외벽이 예상보다 높아 바로 뒤에 배 치되었던 업체들이 상대적으로 조도가 떨어지는 불편함이 있었 다. 독립부스 설계도면을 사전에 충분한 협의 기간을 두고 검토 하여 인접하는 부스와의 배치를 고려할 시간적 여유가 필요하다.

\section{4. 사교행사/식음료}

1) 준비과정 평가

- 사교행사 장소/메뉴 결정

사교행사 장소는 조직위원회의 여러번의 답사를 통해 결정되 었다. 특히 gala dinner와 farewell party는 코엑스 밖에서 이 뤄지는 만찬이고 장소에 따라 진행 컨셉이 달라지기 때문에 여 러요소들을 고려하였다.

〈사교행사 장소 선택 시 고려사항〉

- 수용 가능 인원

- 장소의 상징성

- 메뉴의 다양성 음식의 질/맛

- 행사별 컨셉과의 조화

- 예산

• 공연/부대 행사 결정

각 행사 별 Venue가 결정된 후, 구체적인 공연 컨셉에 대한 논의가 이루어졌다. 특히 사교행사위원장과 공연기획 업체, $\mathrm{PCO}$ 가 하나의 공연 연출을 위해서도 여러 차례 미팅, 리허설 을 통해 진행상황에 대한 점검을 면밀히 확인하고 조율하였다.

단순히 한국적인 공연만을 선택기준으로 삼지 않았고, 소아
치과와 관련된 스토리를 담은 공연, 참가자들의 적극적인 참여 를 유도할 수 있는 공연, 한류의 현재를 보여줄 수 있는 공연 등 으로 지루하지 않으면서도 임팩트 있는 공연을 구성하고자 하 였다.

(2) 사후 평가

- 사교행사 장소/메뉴 결정

공식 사교행사 중 양식 메뉴를 2 회, 한식 메뉴를 1 회 제공하 고, 사전에 특이 식단을 제공해야 하는 참가자들을 파악하여, 다른 메뉴 선택이 가능하도록 선택의 폭을 넓혔다. 특히 $\mathrm{BBQ}$ 뷔페의 경우 $\mathrm{BBQ}$ 메뉴 뿐 아니라 구운 야채와 샐러드 바의 메 뉴를 늘려, vegetarian들도 만족할 수 있었다. 한식을 제공하기 힘든 워커힐 케이터링(standing reception)의 단점은 비빔밥 이벤트와 떡볶이 이벤트를 통해 보완하여 외국인 참가자들에게 큰 호응을 얻었다. 다만 워커힐이 처음 진행한 비빔밥 이벤트는 보여지는 임팩트는 긍정적이었지만, 음식 맛과 질에 대해서는 부정적인 평가가 있었다.

- 공연/부대 행사 결정

개회식의 경우, 사전에 명확한 컨셉을 잡고 그에 적합한 공연 을 더해나간 방식이 임팩트 있는 결과를 넣는데 도움이 되었다. 특히 gala dinner의 경우 야외에서 열린 자유로운 바비큐 파티 의 컨셉에 맞게, 칵테일 쇼에서 시작하여 강강수월래로 다 함께 마무리하는 기승전결이 명확한 프로그램으로 구성될 수 있었던 데는 각 프로그램들을 유기적으로 구성하기 위한 디테일한 논 의가 있어서 가능했다.

(3) 개선 사항

- 식음료 수량 관리

점심 도시락 수요에 대한 리스크 관리 방안으로 현장에서 현 금으로 대체하여 식사비를 지급하기로 한 방안의 현실적 검토 가 부족하였다. 해외 참가자의 참석비율을 고려, 첫날 도시락은 등록인원에 준하여 넉넉하게 준비하고 다음 날의 필요 수량은 첫날의 도시락 수요에 준하여 결정하는 것이 리스크 관리에 용 이할 것으로 판단된다. 해외 참가자가 많을 경우 vegetarian 메 뉴 선택 시 맛과 재료에 좀 더 질을 높일 수 있도록 신경써야 함. 또한 특이 식단에 체크를 하지 않은 참가자가 예상했던 vegetarian 인원보다 약 2.5배 많은 상황이 되었던 만큼, 국가 별 참가율을 고려하여 첫 날에는 사전에 신청인원 보다 약 2 배 많은 인원을 vegetarian 메뉴로 넉넉하게 준비할 필요가 있다.

- 사교행사 장소 및 공연/부대 행사 선정

우천 시에 대한 대비는 미리 해두었지만, gala dinner와 farewell party 모두를 야외로 선정한 것은 위험요소가 있었다. 불가피한 상황이 아니라면, 야외에서 reception을 하고 실내에 서 만찬을 진행하는 방식 등으로 구성을 변화할 수 있는 공간이 있다면 리스크를 줄일 수 있을 것으로 생각된다.

어린이 브라스 밴드의 립싱크 연주와 밋밋한 구성이 조금 아쉬 웠던 만큼 어린이 공연을 선택할 때는 사물놀이 표지훈 어린이와 같이 확실하게 증명된 공연자를 선정해야 할 것으로 판단된다. 


\section{III. 분야별 세부 추진 내용 및 결과}

1. 등록

1) 등록비

(1) 대회 등록비

등록비 책정은 IAPD 대회 기준에 준하는 금액으로 책정하고 (전차 대회와 비슷한 수준) IAPD 본부에 최종 보고/협의 후 확 정하였다. 국내 참가자는 대회 개최국으로서 대한소아치과학회 회원들에게 약 $20 \%$ 할인된 등록비를 책정하였다. IAPD 대회 개최국 중 처음으로 저개발 국가 참가자들을 위해 할인된 등록 비를 책정하였다. World Bank에서 구분한 저개발국과 개발도 상국들을 $\mathrm{A}, \mathrm{B}$ 등급으로 분류하여 등록비 할인혜택을 제공함으 로써 향후 세계학술대회에서 저개발국 혹은 개발도상국에 대한 등록비 할인에 대한 새로운 모델을 제시하였다(Table 7).

\section{(2) Pre-congress 코스 등록비}

Pre-congress 등록비는 무료 등록으로 진행할 경우, 참가 신 청만하고 강의 당일 현장에는 나타나지 않을 확율이 높은 점을 감안하여, 유료로 금액을 책정하였다. 행사장 임대료, 기자재 임대료, 전일 코스의 경우 점심 도시락 비용을 감안하여 금액을 책정하였다(Table 8).
(3) 사교행사 참가비

사교행사의 경우, 메뉴와 행사장소 후보가 검토된 후, 전체 예산의 약 80\%는 참가자 등록비로 충당할 수 있도록 책정하였다.

6월 14일 쉐라톤 워커힐 호텔에서 개최된 gala dinner의 경 우 국내 참가자는 12 만원, 해외 참가자는 미화 $\$ 110,6$ 월 15 일 삼청각에서 개최된 farewell party는 국내 참가자이 경우 8 만원, 해외 참가자는 미화 $\$ 70$ 을 책정하였다.

(4) 등록비 포함 내역

동반자 등록의 경우 학술 강의장 출입이 안되며, 점심과 커피 를 제공하지 않았다(Table 9).

2) 등록 관련 정책

(1) 등록 기간 및 환불 정책

- 등록 기간

- Early Bird(1차 사전등록): 2012년 11월 2013년 4월 15일

- $\operatorname{Early}$ (2차 사전등록): 2013년 4월 16일 5월 12일

- On-site(현장등록): 2013년 6월 12일 15일

- 등록비 환불 정책[기존]

- 2013년 4월 15일 이전에 취소할 경우 전액환불

- 2013년 4월 16일 5월 12일 이내에 취소할 경우 50\% 환불

- 2013년 5월 13일 이후 취소할 경우 환불불가

Table 7. Registration fees

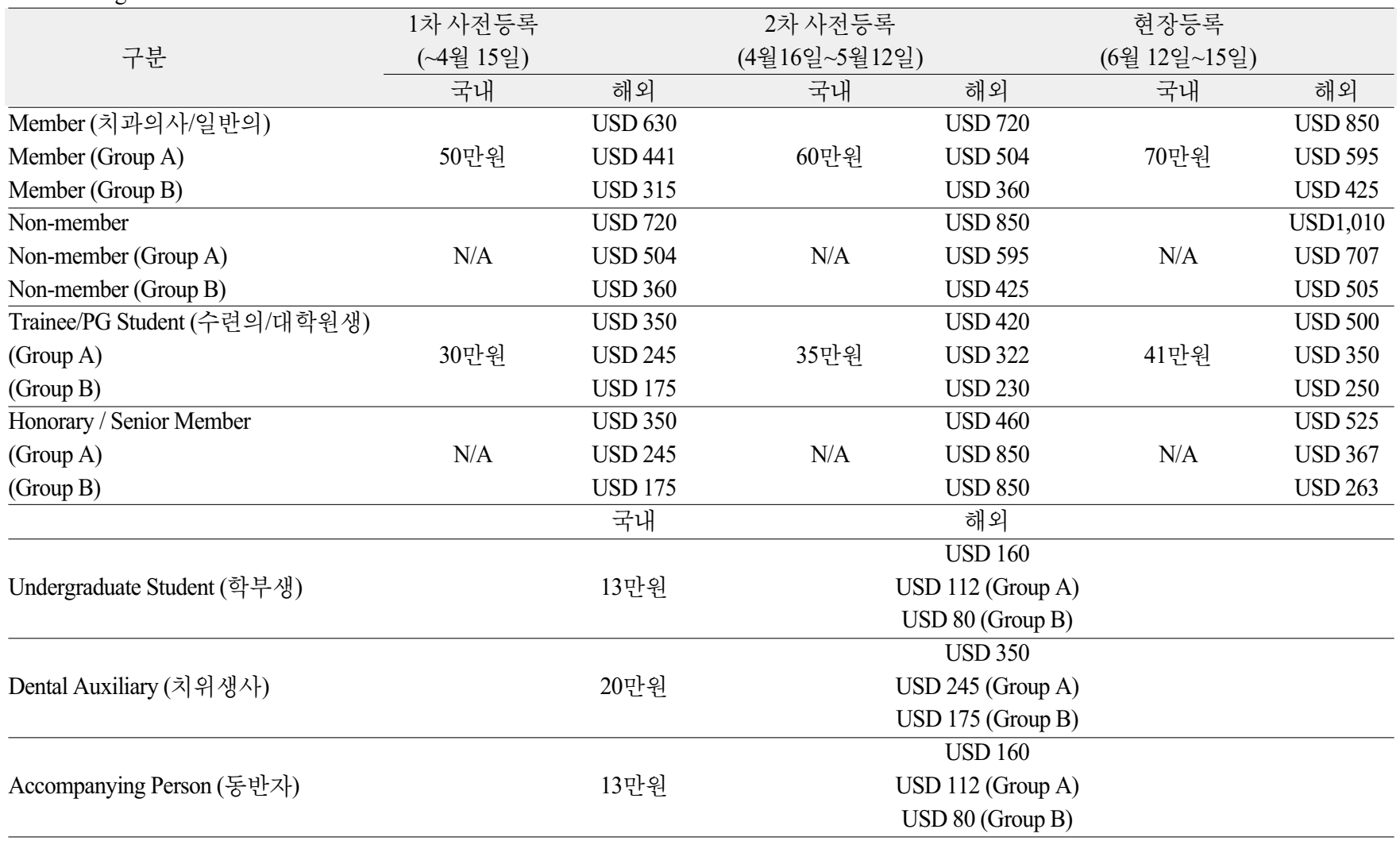

* Discounted registration fee was applied to nations as above according to the database of income level from World Bank. 
Table 8. Registration fees for pre-congress course

\begin{tabular}{|c|c|c|c|c|}
\hline No & 강연 제목 & 연자 & 국내참가자 & 해외참가자 \\
\hline 1 & $\begin{array}{l}\text { Pre-Congress Postgraduate Student Workshop: } \\
\text { When things go wrong - Clinical failures in } \\
\text { paediatric dentistry }\end{array}$ & $\begin{array}{l}\text { - Angus Cameron } \\
\text { - Mike Harrison }\end{array}$ & 2만원 & $\begin{array}{c}\text { USD } 20 \\
\text { Group A: USD } 14 \\
\text { Group B: USD } 10\end{array}$ \\
\hline 2 & Contemporary Sedation in Paediatric Dentistry & $\begin{array}{l}\text { - Eduardo A. Alcaino } \\
\text { - Stephen Wilson }\end{array}$ & 15 만원 & $\begin{array}{l}\text { USD } 150 \\
\text { Group A: USD } 105 \\
\text { Group B: USD } 75\end{array}$ \\
\hline 3 & $\begin{array}{l}\text { Pre-Congress Workshop in Oral Hygiene: } \\
\text { Instruction and Monitoring Caries Activity }\end{array}$ & $\begin{array}{l}\text { - Evert van Amerongen } \\
\text { - Ji-YeonKim } \\
\text { - Marcelo Bonecker }\end{array}$ & 6만원 & $\begin{array}{c}\text { USD } 60 \\
\text { Charge free } \\
\text { for underdeveloped countries }\end{array}$ \\
\hline 4 & $\begin{array}{l}\text { Pre-Congress Hands-on Seminar: } \\
\text { ClinicalApplicationofResinInfiltration }\end{array}$ & $\begin{array}{l}\text { - Jin-Ho Phark } \\
\text { - Vera Soviero }\end{array}$ & 5만원 & $\begin{array}{c}\text { USD } 50 \\
\text { Group A: USD } 35 \\
\text { Group B: USD } 25\end{array}$ \\
\hline 5 & $\begin{array}{l}\text { Pre-Congress Seminar: Anterior and Posterior Ceramic } \\
\text { Pediatric Crowns - Hands on Instruction }\end{array}$ & $\begin{array}{l}\text { - William Waggoner } \\
\text { - Ray Stewart } \\
\text { - AnneO'Connell }\end{array}$ & 5만원 & $\begin{array}{c}\text { USD } 50 \\
\text { Group A: USD } 35 \\
\text { Group B: USD } 25\end{array}$ \\
\hline
\end{tabular}

Table 9. Registration fee entitlements

\begin{tabular}{lcc}
\hline 포함내역 & $\begin{array}{c}\text { 회원, 비회원, } \\
\text { 대학원생/학부생, 치위생사 }\end{array}$ & \begin{tabular}{c} 
동반자 \\
\hline 모든 학술장 출입
\end{tabular} \\
전시장 출입 & $\mathrm{O}$ & $\mathrm{X}$ \\
개회식 & $\mathrm{O}$ & $\mathrm{O}$ \\
환영만찬 & $\mathrm{O}$ & $\mathrm{O}$ \\
커피 브레이크 & $\mathrm{O}$ & $\mathrm{O}$ \\
점심 & $\mathrm{O}$ & $\mathrm{X}$ \\
킷 가방 (초록집\&프로그램북 등) & $\mathrm{O}$ & $\mathrm{X}$ \\
\hline
\end{tabular}

\section{- 등록비 환불 정책 [변경]}

북한의 미사일 위협으로 인한 한반도 정세에 대한 불안전한 상황이 도래한 이후, 5 월 12 일까지의 모든 환불 요청은 $100 \%$ 환불을 해주기로 하였다. 조직위원장의 한반도 안전에 대한 강 한 확신을 전달하는 동시에 외국인 참가자들의 사전등록 이탈 을 막기 위해 5 월 12 일까지로 환불 정책을 변경 하였고 이는 해 외 참가자들의 등록 취소를 막는 결정적인 요인이 되었다.

5 월 12 일 이후 환불요청은 천재지변이나, 전쟁과 같은 불가 피한 상황이 아닌 경우 환불을 해주지 않도록 규정을 공지하였다.

(2) 저개발 국가 할인 적용 기준

- Group A, B 할인 등록비 책정 배경

저소득 국가(동남 아시아를 비롯)의 참가자들이 할인된 등록 비를 통해 보다 많이 서울 학회에 참여할 수 있는 기회를 제공 하고자 하였다.

- 선정 기준 및 해당 국가리스트

세계은행 (www.worldbank.org)에서 정한 income level 기 준에 따랐다.
(3) 등록비 결제 방법

(1) 카드 결제 (온라인 카드 결제)

- 결제 방법에서 Credit card 설정 $(\mathrm{KCP}$ 결제 모듈 설치 필요)

- 카드번호와 만료일 기입 후 결제

- 결제 가능 카드

- 국내: 모든 시중은행 신용카드

- 국외: Master,VISA, JCB 만

- $\mathrm{KCP}$ 입금 확인 후 confirmation letter 발송

(2) 은행 송금

- 결제방법에서 은행송금 설정

- 송금자 란에 참가자 이름 기입

- 결제통장 계좌번호 안내(원화, 외화 등록비 통장 별도 운영)

- 등록비 통장에서 입금 확인 후 confirmation letter 발송

(3) 카드 결제 (수기 결제 - 온라인 카드 결제가 안될 경우)

- 해외 참가자의 온라인 신용카드 결제 문제 발생시를 대비

- 결제방법에서 credit card manual 설정 후 결제에 필 요한 본인의 카드 정보 기입(카드 번호/만료일 등 중 요 개인정보는 암호화)

- 사무국에서 신청된 참가자의 카드정보를 관리자 페이 지에서 확인 후 수기 결제를 진행, 카드사 승인후 confirmation letter 발송

3) 등록 절차 및 관리

(1) 참가자 등록

해외 등록비와 구분된 원화 등록비가 책정된 국내 참가자는 별도의 등록페이지를 구성하여(절차는 해외 참가자와 동일) 대 한소아치과학회 홈페이지(www.kapd.org)를 통해서 별도 등 
록 페이지에 접속할 수 있도록 안내하였다.

- 참가자 등록 절차(온라인 등록)

IAPD 2013 홈페이지 방문 $\rightarrow \mathrm{ID}$ 생성 (Sign up) $\rightarrow$ 온라 인 등록 및 결제 완료 $\rightarrow$ Acknowledgement of Registration 발송(온라인 등록 확인증) $\rightarrow$ 사무국에서 등록비 결제/입금 확인 $\rightarrow$ Confirmation letter 발송(입 금/등록 완료 확인증)

- 참가자 등록 절차(오프인 등록)

오프라인 등록 양식 작성 $\rightarrow$ 사무국에 Fax나 e-mail을 통 하여 제출 $\longrightarrow$ 사무국에서 ID 대리 생성 $\rightarrow$ 등록비 결재 (은 행송금/카드결제/카드결제의 경우 사무국에서 수기결제) $\rightarrow$ Acknowledgement of Registration 발송 $\rightarrow$ 등록비 입금/결제 완료 $\rightarrow$ Confirmation letter 발송

(2) 참가자 관리

(1) Website에서 관리자 페이지의 운영

〈관리자 페이지 구성〉

- Registration number, e-mail, Last name으로 등 록자 검색 가능

- 국가 별, 등록여부 별, 등록 카테고리 별 정렬 가능

- 등록자 관련 상세 정보 표기

- 초청연사, 좌장, 참석여부 별도 표기 구분

- 참가자 등록 카테고리 변경 가능

- 참가자 결제정보 및 등록비 결제 상태 변경 가능

- Confirmation letter, Invitation letter 발송 가능

- 실 등록비 입력용 수기등록비/수수료 기입란 가능

- 참가자 등록 전체 정보 수정 가능 팝업 창 구성

- 등록 카테고리 및 Pre congress, Social event 유/무 료 설정가능

(2) 등록 관련 문의 응대

〈등록 관련 문의〉

- IAPD 멤버 유무에 따른 등록비 차이에 대한 문의

- Group A, B에 포함여부에 따른 등록비 문의

- 카드 수기결제 시 오류 문의

- 영수증 요청

- 추가 사교행사 티켓 구매 문의 등

〈참가자 비자 관련 문의〉

- Invitation letter 이메일 및 우편 요청

- 신원보증 요청 관련 서류 발송

〈그룹등록 관련 문의〉

- 수리남 4명, 네팔 5명, 칠레 7명, 필리핀 27명, 태국 31명

- 그룹 등록의 경우 예외적 등록비를 일부 적용

- 필리핀: 20명 이상 단체등록 시 Group A 비회원 (\$504)이 아닌 Group A 회원 등록비 (\$441) 적용

- 태국: 30명 이상 단체등록 시 IAPD 비회원 $(\$ 720)$ 이 아닌 회원등록비 $(\$ 630)$ 로 적용

- 이란: 이란에 대한 국제사회의 경제 제재를 감안,
초록제출자 대상으로 Group B 등록비 $(\$ 315)$ 적용 $\langle\mathrm{FAQ}$ 를 대비한 참가자 편의 기능 사전 제공(마이페이지)〉 - 등록 상황 체크 가능 (payment ongoing, completed)

- 등록비 결제 후 invitation letter 마이페이지에서 출 력 가능

- 실제 대회 참가 후 certificate of attendance 마이페 이지에서 출력 가능

〈현장 등록 업무 편의를 위한 Barcode Email/문자 발송〉

- 모든 사전등록자에게 개별 등록정보가 입력된 바코드 이메일을 발송: 현장에서 출력한 바코드를 스캔할 경 우 바로 등록자 정보가 화면에 보이고 명찰을 출력할 수 있는 시스템을 활용

- 국내 참가자에게는 바코드가 포함된 안내 문자 발송

4) 등록현장 관리

(1) 등록 데스크 운영 개요

(1) 운영시간 및 장소

- 6월 12일(수) 08:00 18:00 코엑스 그랜드볼룸 로비 $(1 \mathrm{~F})$

- 6월 13일(목) 07:30 18:00 코엑스 그랜드볼룸 로비 (1F)

- 6월 14일(금) 07:30 18:00 코엑스 그랜드볼룸 로비 (1F)

- 6월 15일(토) 07:30 16:00 코엑스 그랜드볼룸 로비 $(1 \mathrm{~F})$

(2) 등록관련 현장 업무

- 5월 31일 사전등록 마감 및 각 등록 리스트 정리

- 6월 5일 등록 데스크 운영요원 1차 사전 교육

- 6 월 7일 리본 부착 및 사전 명찰 출력 및 좌장/연자 봉투 작업

- 6월 11일 Congress Kit(등록 가방) packing 작업 등록 데스크 및 긍록 시스템 setting

- 6월 12일 등록 데스크 운영요원 2차 사전 교육 및 리허설 실시

(3) 등록관련 준비물품

- 등록 Master DB/바코드 등록 시스템

- 현장등록 신청서(국/영문),

- 사교행사 티켓 및 추가 판매 티켓

- 영수증 및 기타 물품(명찰 케이스/줄, 명찰 내지, 문구 류 등)

- Lunch Coupon

- Certificate of Session Attending Hours

- Congress Kit 1,500개

(4) 등록 데스크의 구성

국내 및 해외 참가자의 비율을 고려하였다. 국내 사전 등 록데스크 2 개(4명), 해외 등록데스크 2 개(4명), 현장 등 록 1 개 ( 2 명), 초청 연자 및 좌장 디스크 1 개( 2 명)

(5) 등록 데스크 기자재 운영 
출력용 $\mathrm{PC}$ 와 프린터 각각 7대, 노트북 3대, 레이저 프린 터 1대(투어), 전화기 2대, 전화선 4개, 인터넷 라인 6 개, 차단봉 165 개, 무전기 2 대, 휴지통 1 개, 금고 1 개를 비치하였다.

(6) 참가자 명찰구분

참가자의 명찰은 명찰 바탕색이나 디자인에는 차이를 두 지 않고 하단에 색상이 다른 천을 추가로 부착하여 식별 하도록 하였다(Table 10)

(2) 등록 데스크 현장 운영

(1) 데스크 별 업무 및 역할(Table 11)

(2) 데스크 운영 특이사항

- 사전등록 데스크

언어별 특기자(중국어, 영어) 를 배치하여, 등록데스 크 운영 및 응대가 원활할 수 있도록 함. 특히 그룹으 로 데스크를 방문한 중국 참가자들의 응대에 큰 도움 이 되었다.

바코드 등록 시스템을 통해 외국인 참가자의 이름을 확인하는 시간 소요를 줄일 수 있었다. $80 \%$ 이상의 외국인 참가자들이 바코드를 출력하여 데스크를 방문, 업무 처리 속도와 효율을 높였다.
참가자들의 요청이 많을 Certificate of attendance와 $\mathrm{CE}$ points에 대한 응대 방안을 사전에 준비하여 현장 요청에 신속하게 응대가 가능했다.

• On-Site \& Cashier's Desk

미결제 등록비, 환불금액, 사교행사 티켓판매 등을 한 곳에서 처리함으로써 돈을 관리하는 창구를 하나로 단 일화하여 관리가 용이했다.

\section{2. 홍보}

1) 온라인 홍보

(1) 홈페이지

• 공식 홈페이지 URL: www.iapd2013.org

• 메뉴구성: Table 12

(2) 모바일 웹 URL: http://iapd2013.org/m2

- 참가자의 웹사이트 접근성을 높이기 위해 대회 한달 전 오 픈하였다.

-주요기능: 연자정보, 업데이트 학술프로그램 확인, Plenary session, 온라인 Q\&A 게시판 등을 운영

Table 10. Identification of name badges by adding the ribbon of different color

\begin{tabular}{ccccc}
\hline 구분 & 구분 텍 & 대상 & 표시내용 & 비고 \\
\hline Delegate & 파랑 & 일반 참가자 & 이름/국가 & \\
Chairperson & 빨강 & 좌장 & 이름/국가 & 리본 \\
Speaker & 보라 & 연사 & 이름/국가 & 리본 \\
IAPD Board Member & 주황 & IAPD Board Member & 이름/국가/위원 & 리본 \\
Organizing Committee & 노랑 & 조직위원회 & 이름/국가/위원 & 리본 \\
Past President & 은회색 & 역대 IAPD회장 & 이름/국가 & 리본 \\
Pre-Congress & 자주 & 코스 등록자 한함 & 이름//국가 & 종이리본 \\
Accompanying Person & 연두 & 동반자 등록자 & 이름/국가 & 2 단 \\
Exhibitor & 분홍 & 전시업체 & 회사명 & 2 단 \\
Visitor & 진회색 & 전시장 참관자 & 이름/국가 & 2 단 \\
STAFF & 녹색 & PCO/운영요원 & 이름/국가 & 2 단 \\
\hline
\end{tabular}

Table 11. Categories of registration desks and their business

\begin{tabular}{|c|c|c|}
\hline 구분 & 주요업무 & 기타 업무/비고 \\
\hline $\begin{array}{l}\text { 사전등록 데스크 } \\
\text { (국내/국외) }\end{array}$ & $\begin{array}{l}\text { - 사전등록자 명찰 배부 } \\
\text { - Congress Kit 배부 } \\
\text { - Lunch Coupon 배부 } \\
\text { - Gala/Farewell 초청장 배부 (해당사항 있는 등록자만) } \\
\text { - 등록비 미납자 } \\
\text { On-site \& Cashier데스크로 안내 }\end{array}$ & $\begin{array}{l}\text { - 참가자 네임택 배부시 업체 경품 쿠폰 삽입 후 지급 } \\
\text { - 참가확인증 요청시 안내 } \\
\text { (마이페이지에서 직접 출력가능) } \\
\text { - 평점 안내 } \\
\text { (국내: KAPD 부스로 안내, 해외: } \\
\text { Confirmation of attending hours 안내) } \\
\text { - 기타 대회 관련 문의 }\end{array}$ \\
\hline $\begin{array}{l}\text { 현장등록 및 } \\
\text { Cashier's 데스크 }\end{array}$ & $\begin{array}{l}\text { - 현장등록처리, 사전등록 } \\
\text { 미결제자 결제처리, 환불처리, social event 티켓 판매 }\end{array}$ & - 전시장 참관 Pass 판매 \\
\hline $\begin{array}{l}\text { 초청연자 } \\
\text { 좌장 데스크 }\end{array}$ & $\begin{array}{l}\text { - 초청연자, 좌장 명 찰, Congress Kit, 연자/좌장 봉투 배부 } \\
\text { - 연자비 지급 } \\
\text { - 환불 및 결제 처리 } \\
\text { - 프리뷰룸 안내 }\end{array}$ & $\begin{array}{l}\text { - 연자/좌장 봉투는 별도로 준비 (사전 명 찰 출력) } \\
\text { - 대한소아치과학회에서 지급하는 감사비 지급 }\end{array}$ \\
\hline
\end{tabular}


Table 11. Site map of official website for 2013 IAPD congress

\begin{tabular}{|c|c|c|c|c|c|c|}
\hline Ovier view & $\begin{array}{l}\text { Scientific } \\
\text { Program }\end{array}$ & $\begin{array}{c}\text { Abstract } \\
\text { Submission }\end{array}$ & Registration & $\begin{array}{l}\text { Sponsorship } \\
\text { \& Exhibition }\end{array}$ & $\begin{array}{c}\text { Hotel Tour } \\
\text { Social Program }\end{array}$ & $\begin{array}{c}\text { Travel } \\
\text { Information }\end{array}$ \\
\hline $\begin{array}{l}\text { Welcome } \\
\text { Message }\end{array}$ & $\begin{array}{l}\text { Program } \\
\text { at a glance }\end{array}$ & $\begin{array}{l}\text { Call for } \\
\text { Abstract }\end{array}$ & $\begin{array}{l}\text { Registration } \\
\text { Guideline }\end{array}$ & $\begin{array}{l}\text { Sponsorship } \\
\text { \& Exhibition }\end{array}$ & Accommodation & Transportation \\
\hline $\begin{array}{l}\text { Congress } \\
\text { Information }\end{array}$ & $\begin{array}{l}\text { Scientific } \\
\text { Program }\end{array}$ & $\begin{array}{l}\text { Online Abstract } \\
\text { Submission }\end{array}$ & Online Registration & $\begin{array}{l}\text { Sponsors\& } \\
\text { Partners\& } \\
\text { Exhibitors }\end{array}$ & Tour & About Seoul, Korea \\
\hline $\begin{array}{l}\text { Organizers } \\
\text { Committees }\end{array}$ & $\begin{array}{l}\text { Invited Speakers } \\
\text { \& Chairs }\end{array}$ & $\begin{array}{c}\text { Awards } \\
\& \text { Bursaries }\end{array}$ & & & Social Program & Useful Information \\
\hline
\end{tabular}

Table 12. The financial support for the invited speakers

\begin{tabular}{|c|c|c|c|c|}
\hline 조건 & 세부기준 & 연자비 & 제 공내역 & 비고 \\
\hline \multirow{5}{*}{ 지역별 } & 아시아 & $\$ 1,500$ & 등록비 면제 & 본인이 직접 항공권 구매, \\
\hline & 미주/유럽/오세아니아 & $\$ 2,500$ & Gala Dinner 1장 & 호텔 예약 \\
\hline & 대한소아치과학회 회원 & 30 만원 & - & \\
\hline & \multirow{2}{*}{ 국내 타학회 회원 } & 50만원 & 등록비 면제 & \\
\hline & & & Gala Dinner 1장 & \\
\hline \multirow{6}{*}{ 프로그램별 } & Keynote 연자 & 항공권 숙박, 조식 & 등록비 면제 & 연자별 차등조건 \\
\hline & 업체 후원 연자 & - & Gala Dinner 1장 & 업체별 차등지원 \\
\hline & Clinical Practice 연자 & $\$ 500$ & 등록비 면제 & Call for speaker 통해 선발 \\
\hline & \multirow{2}{*}{ Treasure Island 연자 } & - & 감사패, 선물 & \\
\hline & & & Gala Dinner 1장 & \\
\hline & Pre-congress 연자 & & 숙박지원 또는 등록비 면제 & 연자별 차등조건 \\
\hline \multirow{4}{*}{ 기타 } & \multirow{2}{*}{ IAPD Board Member } & - & 숙박지원, 등록비 면제 & \\
\hline & & & Gala, Farewell 2장 & \\
\hline & \multirow{2}{*}{ 타지역 소아치과학회장 } & - & 숙박지원(3박) & \multirow{2}{*}{ 학회장별 차등조건 } \\
\hline & & & Gala Dinner 1장 & \\
\hline
\end{tabular}

(3) 뉴스레터 및 e-mail

(1) 뉴스레터

- 홍보시기: 2012년 10월 2013년 2월

- 발간횟수: 뉴스레터 제 1호 제 5호(영문), 총 5회

- 대상

- 국내: 대한소아치과회원, 관련 전시 업체 총 1,200 명

- 국외: IAPD 2011 전차대회 참가자, IAPD 멤버 총 6,500 명

- 뉴스레터 발송 일정

(2) E-blast

- 홍보시기: 2012년 2월 2013년 7월

- 발간횟수: Eblast 제 1호 제 35호(국/영문)

- 대상

- 국내: 대한소아치과회원, 관련 전시 업체 총 1,200 명

- 국외: IAPD 2011 전차대회 참가자, IAPD 멤버 총 6,500 명

(3) 본부 발송 뉴스레터(IAPD Newsletter)

- 시기: 2012년 4월, 2013년 3월

- 발간횟수: 1 회/57개국 약 15,000 명

- 대상: IAPD 전체 회원(본부에서 직접 발송, 홈페이지 게재)
(4) SNS

E-blast보다 더 캐주얼한 방법으로 한국의 다양한 문화와 관 광지를 소개함. 직접 찍은 사진 등을 통해 서울의 이미지를 친 근하고 가깝게 느낄 수 있도록 안내하였다. 주요 마감일의 공지 및 상기 효과가 높게 나타났다.

- 페이스북 URL: https://www.facebookcom/iapd2013

- 총 441 page like 및 친구 268명

- 학술대회 기본 정보 및 한국 관광 정보 안내

- 참가자 대상 등록/참여 독려 이벤트 실시

(5) Communication supporter

- 해당 학회 웹사이트를 통해 IAPD 2013 서울 대회 홍보에 도움을 준 학회, 협회(웹배너 링크, 일정 공지, 뉴스레터 발 송 등)

- EAPD(The European Academy of Paediatric Dentistry)

- AAPD(The American Academy of Pediatric Dentistry)

- PDAA(Pediatric Dentistry Association of Asia)

- ALOP(Latin American Pediatric Dental Association)

- IADT(International Association of Dental Traumatology)

- iADH(International Association for Disability and 
Oral Health)

- ANZPD(The Australian \& New Zealand Society for Paediatric Dentistry)

- HSPD(Hellenic Society of Paediatric Dentistry)

- NVvk(Dutch Association of Paediatric Dentistry)

- Brazilian Association of Pediatric Dentistry

- Peruvian Society of Pediatric Dentistry

- SVK · ASP(Swiss Society of Paediatric Dentistry)

- Israeli Society of Dentistry for Children

- JSPD(Japanese Society of Pediatric Dentistry)

- TAPD(Taiwan Academy of Pediatric Dentistry)

- ISPPD(Indian Society of Pedodontics \& Preventive Dentistry)

- Philippine Pediatric Dental Society

- ISDC(The Irish Society of dentistry for children)

- Egyptian Society for Pediatric Dentistry and Children with Special Needs

- CSPD(Cambodian Society of Paediatric Dentistry)

- Swedish Society of Paediatric Dentistry

- Norwegian Society of Pedodontics

- Asociación Panameña de Odontologia Pediatrica

- SIOI(Italian Society of Pediatric Dentistry)

(6) Media supporter

온라인 또는 오프라인 저널/신문/웹사이트를 통해 IAPD 2013 Seoul 대회 홍보에 도움을 준 미디어 파트너(대회 일정 게재, 대회 소개, 인터뷰 요청 등)

- International Journal of Pediatric Dentistry

- Caries Research

- Pediatric Dentistry

- European Achives of Paediatric Dentistry

- European Journal of Paediatric Dentistry

- IADH Magazine

- Dental Tribune

- fdi News

2) 국내외 연관 학회 홍보

(1) 국내 연관학회

국내 19 개 학회에 공식 공문을 보내 회원들의 참가 협조 요청

(2) 해외 연관학회

62 개국 소아치과학회와 4개 대륙학회에 e-mail 공식 서한을 발송하여 참가 협조 요청 및 홍보 요청

3) 오프라인 홍보

(1) 해외 학회 홍보: 앞에서 기술

(2) 국내 학회 홍보
제 28회 KIMS, 2012년도 대한장애인치의학회 학술대회, 아 시아태평양 치과근관치료학회 학술대회, SIDEX 2013

(3) 오프라인 홍보 물품

1 차, 2 차 학회 안내서(영문판), 홍보 동영상, 마우스패드, 버 튼, $\mathrm{X}$-배너 및 통천 현수막, 전자파 차단 스티커(서울관광마케 팅 지원), 관광가이드북(한국관광공사 지원)

\section{3. 학술}

1) 개요

(1) 업무 흐름도

학술 프로그램 기획 후 각 part별 업무 flow chart는 다음과 같다.

(1) 초청강연

초청등급 결정 $\longrightarrow$ 초청연자 선정 및 $\mathrm{DB}$ 구축 $\rightarrow$ 초청 서 진 발송 $\rightarrow$ 초청수락시 발표주제 수령 $\rightarrow$ 초청 연자 세션 별 배정 $\rightarrow \mathrm{CV}$ 및 초록 접수 $\longrightarrow$ 좌장 선장 및 초청 $\longrightarrow$ 발 표 및 좌장 가이드라인 안내문 발송

(2) 구연 및 포스터 발표

초록 접수 및 review 방침 결정 $\rightarrow$ Call for abstract $\rightarrow$ Topic category결정 $\longrightarrow$ 온라인 초록 접수 $\rightarrow$ Review 및 세션 배정 $\rightarrow$ Acceptance notice 및 발표 가이드 라인 발송 $\rightarrow$ 좌장 선정 및 배정 $\rightarrow$ 발표 및 좌장 가이드라인 안내문 발송

(3) Award

초록 접수 및 award 신청 접수 $\rightarrow \mathrm{IAPD}$ 본부로부터 최 종 신청자 확인 $\rightarrow$ 후보 초록 공지 및 현장 심사 준비 $\rightarrow$ 현장심사 좌장 선정 $\rightarrow$ 발표 및 좌장 가이드라인 안내문 발송

이후 각 part별 현장 운영계획 수립 $\rightarrow$ 초록집 및 프로그램집 발주 $\rightarrow$ 발표 기자재 조달 $\rightarrow$ 진행 요원 선발 교육 $\rightarrow$ 최종 리허 설과 같은 과정을 통하여 추진되었다.

(2)학술프로그램의 구분

(1) 초청 강연: 강연( 1 10개 session), 심포지움 $(1 \sim 6$ 개 session)기타 포맷 15 개 강연

(2) 일반 세션: 구연(1 20개 session), 포스터(1 18개 session) 등 총 679편 일반 연제 발표

(3) 기타 세션: Pre-Congress Course(5개 session)

(3) 주요 일자

(1) 초록 접수 마감

- 초청연제: 2012년 2월 29일(수)

- 일반초록: 2012년 1월 31일(화), 2012년 2월 29일(수)

(2) 초록 심사 마감일: 2010년 7월 12일(월)

(3) Poster acceptance notice 발송: 2012년 3월 19일(월) 
(4) Oral acceptance notice 발송: 2012년 3월 27일(화)

(5) Oral to poster acceptance notice 발송: 2012년 3월 18일(수)

(6) 발표자 등록마감: 2012년 4월 10일(화)

(7) 발표자료 제출 마감일: 2012년 5월 20일(월)

2) 초청 연자 관리

(1)초청 연자 및 좌장 섭외

(1) 초청 연자

- Keynote speaker: 대회 약 2년 전 확정, 기타 연사는 약 1 년전 확정하였다.

- 각 분과별로 후보 연자 명단을 초기에 학술위원장의 추 천으로 구성하였다.

- 각 분과별 담당위원이 분과의 위원들과 논의하여 초기 구성안을 바탕으로 최종 연자 후보 명단을 구성하였다.

- 학술위원회 및 조직위원회에서 지역별, 성별, 영향력, 업체 후원 여부 등을 고려하여 분과별로 최종 선정하였 다.

- 부득이하게 1 순위의 연자가 수락하지 못하였을 경우, 차선 후보 중 역시 지역 및 성별 안배 등을 고려하여 선 정하였다.

(2) 좌장

- 대회 약 3 4개월 전 확정하였다.

- 좌장에게 따로 지급되는 수고료가 없기 때문에, 사전 등록 마감일 기준 등록자를 참고하여 좌장 후보를 검토 하였다.

(3) 초청업무

- 1 차 공식 초청장 발송(의향, 일정 확인)

- 2 차 공식 초청장 발송(초청조건 명기, 발표할 주제 요 청)

- 수락 의사 확인 후 연자별 별도 초청조건 협의가 필요 한 부분은 최종 확정하여 진행하였다(항공권 결제 주체 등).

(4) 초청조건(Table 12)

(2) 초청 연자 및 좌장 관리

(1) 초록 관리

- 온라인 접수: 대회 홈페이지를 통해 접수/초청초록 제 출을 선택할 경우, 글자수 제한 없이 자유롭게 입력 할 수 있게 하였다.

- 오프라인 접수: 온라인 접수를 기한 내 하지 못한 연자 의 경우에는 이메일로 초록을 접수 받았다.

(2) 등록 관리

- 온라인 등록 1차 유도

온라인 등록 시스템에서 연자들의 등록비가 0 으로 셋 팅되어 있지 않았으나, 관리의 편의성과 정보 입력의 정확도를 위해 연자들이 직접 홈페이지를 통해 등록하 도록 안내하였다.
- 이메일 등록 2 차 유도

1 차 사전등록마감일에도 약 $50 \%$ 연자는 미등록 상태 였으므로, 사무국에서 대신 온라인 등록을 진행하고, 등록 기본 정보를 연자에게 이메일로 확인하여 등록률 을 높였다. 대부분의 연자가 등록비를 면제 받고 gala dinner 를 제공받았기 때문에, 추가로 유료로 신청하 는 항목이 있지 않는 한 직접 등록하는 비율이 낮았다.

(3) 항공권, 숙박 관리

- 항공권 구매

항공권을 제공하는 기조 연자의 경우, 연자와 협의하여 진행하였다. 해외에서 직접 예약하는 경우와 한국에서 예약하는 경우중 예산을 절감할 수 있는 방향으로 시행 하였다. 대한항공 제휴 할인(20\% 이코노미, $10 \%$ 비지 니스)을 적용한 금액으로 연자의 항공권을 구매하였다.

- 숙박 예약

조직위원회에서 숙박을 제공하는 경우를 제외하고 개 별 예약을 연자가 직접 할 수 있도록 안내하였으며, 온 라인 또는 오프라인 폼을 통해 housing bureau로 호 텔 예약을 직접 할 수 있도록 안내하였다.

(4) 기타

- 사전 커뮤니케이션 유도

학술위원회에서는 invited session의 각 세션별 담당 자를 지정하여, 사전에 coordinator로서의 역할을 부 여하였다. 각 세션의 연자들과 이메일을 공유하여 그룹 커뮤니케이션, 사전 디스커션 등을 통해 프로그램의 내 용이 중복되지 않고, 토론이 활발히 진행될 수 있도록 조율하였다.

(5) 현장 관리

\section{- 초청연자 수송 관리}

초청연자에게 pick up service를 제공하는 대신, 공항 에서 운영하는 IAPD 2013 안내데스크에서 공항버스 티켓을 제공하고 교통편을 안내해 주는 편의를 제공하 였다. 일부 의전이 필요한 대상은(board Member 등) 전문 의전 서비스를 제공하여 사전 비행기 스케줄에 맞 춰 공항 픽업 서비스를 제공하였다.

• 초청연자 및 좌장 현장부재(no-Show) 관리 초청연자 등록데스크를 별도로 운영하여, 가이드라인 전달 및 프리뷰룸 유도, 세션룸 안내 등을 바로 할 수 있도록 하였다. 초청연자의 경우 현장에 나타나지 않는 경우가 없었으나. 포스터 좌장의 경우 현장에 나타나지 않는 경우가 있었다. 이를 방지하기 위해 세션별 학술 위 담당자를 지정, 현장에서 빠르게 대응할 수 있도록 하였다. 또한 프리뷰 룸/등록데스크 등과 긴밀하게 커 뮤니케이션하여 연자/좌장의 등록, 발표자료 제출 여 부를 실시간으로 확인할 수 있게 하였다.

- 초청연자 여행경비(travel expense)/강사료 관리 여행경비/강사료는 프리뷰 룸에서 관련 서류/영수증을 사인 받고 전달하였다. 외국연자의 경우 여권사본과 항 
공권 사본을 요청하였으며 국내연자의 경우 신분증 사 본으로 관련 서류를 대체하였다.

- 기타 연자/좌장 관리

현장에서 필요한 요청사항들의 대부분은 등록데스크 또는 프리뷰룸에서 응대가 가능했다. 연자들의 발표자 료 및 copyright과 관련된 사항은 프리뷰 룸에서 통제 했고, 기타 연자들의 숙박, 등록, 사교행사 티켓 구매, 관광 등과 관련된 문의는 등록데스크에서 처리하였다.

(3) 초청 연자 및 좌장 lists

초청연자 총 85 명. 초청강연 좌장 총 44 명〈프로그램집 참조〉

(4) 초청강연 연재〈프로그램집 참조〉

(5) 일반 연재

(1) 발표 타입별 접수현황(2월 29일 기준) (Table 13)

(2) 국가별 접수현황(2월 29일 기준) (Table 13)

(3) Topic별 접수현황(2월 29일 기준) (Table 14)

(6) 기타 세션

(1) Pre-Congress Session 일시: 2012년 6월 12일(수), 09:00-16:00

- Postgraduate Student Workshop: When things go wrong-Clinical failures in paediatric dentistry - Angus Cameron(Australia)

- Mike Harrison(UK)

- Contemporary Sedation in Paediatric Dentistry

- Eduardo Alcaino(Australia)

- Stephen Wilson(USA)

- Dimitris Emmanouil(Greece)

- Douglas Stewart(Australia)

- Workshop in Oral hygiene: Instruction and Monitoring Caries Activity

- Willemc Amerongen(Netherlands)

- Marcelo Bönecker(Brazil)

- Ji-Yeon Kim(Korea)

- Hands-on Seminar: Clinical Application of Resin Infiltration

- Jin-Ho Phark(USA)

- Vera Soviero(Brazil)

Table 13. Abstract submission statistics by presentation type

\begin{tabular}{cccc}
\hline 구분 & 국내 & 국외 & Total \\
\hline Oral & 36 & 123 & 159 \\
Poster & 194 & 280 & 474 \\
Oral or Poster & 17 & 105 & 122 \\
Invited Lecture & 3 & 25 & 28 \\
Total & 250 & 533 & 783 \\
\hline
\end{tabular}

- Anterior and Posterior Ceramic Pediatric CrownsHands on Instruction

- Anne O' Connell(Ireland)

- Ray Stewart(USA)

- William Waggoner(USA)

(2) Lunch \& Learn

- Ceramic pediatric crowns - when, where, how \& why(NuSmile)

- 일시: 6월 13일(목), 12:15-13:15 장소: GBR $101+102(1 \mathrm{~F})$

- Possibility of bioactive materials containing Surface Pre-Reacted Glass-ionomer filler(Shofu) - 일시: 6월 13일(목), 12:15-13:15 장소: GBR 103(1F)

- Management of Early Caries Lesions - current thoughts and strategies (3M)

- 일시: 6월 14일(금), 12:45-13:45 장소: GBR 103(1F)

(7) Award

Award와 관련된 모든 사항은 기본적으로 IAPD 본부에서 관 리한다. 올해에는 IAPD 2013 홈페이지를 통해 초록제출 시 award 신청 여부를 체크하는 란을 만들어서 award에 대한 정 보를 제공할 뿐 아니라 실제 award 를 본부에 신청한 참가자와

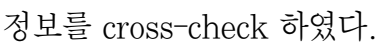

(1) The Bright Smiles, Bright Futures Award(BSBF Award)

- IAPD 본부로 직접 신청 및 관련 자료 제출

- 6 월 12 일(수)에 최종 선정자들만 별도 공간에서 발표 및 심사

- 선정 인원: GRAND prize WINNERS 1인, WINNERS 3 인

(2) The Jens Andreasen Award \& The Morita Prizes

- 대상: IAPD 포스터 제출자 중 IAPD 본부에 award 신청을 한 자

- 포스터 전시: 6월 13일(목) 15일(수)

- 포스터 발표: 6월 14일(금), 14:00-15:30

- 심사: IAPD 본부에서 별도로 선정

- 선정 인원: The Jens Andreasen Award 1인

The Morita Prizes 2인

3) 세션 룸 현장 운영

운영의 기본 방침

(1) 기조 강연 세션룸 운영 방식

- 각 룸별로 2 명의 운영요원, 1 명의 기술요원을 기본으로 하 였다.

시스템이 복잡하고, 참가 인원도 많은 중요 세션인 만큼 기조 강연은 3 명의 운영요원, 3 명의 기술요원으로 운영하였다.

- 기조 강연은 대형 스크린(워치 아웃 시스템)을 최대한 활용 
하고 연자들이 무대를 자유롭게 이동할 수 있도록 핀마이 크를 사용하였다.

- $\mathrm{Q} \& \mathrm{~A}$ 실시간 게시판 운영

기조 강연시 실시간으로 온라인 게시판에 질문을 올리고, 좌장이 지속적으로 확인/청중들과 질문을 공유하는 형태의 토의시간 을 운영하였다.

2) 일반 세션룸 운영 방식

- 각 룸별로 2 명의 운영요원, 1 명의 테크니션을 기본으로 운 영하였다.

- 프리뷰 룸과 지속적으로 커뮤니케이션, 최종 발표 자료를 세션 시작 30 분 전까지 확보하였다.

- 세션 시간 변경/연자 no-Show 등의 상황을 좌장에게 공지 하였다.

- 각 룸별/세션별 담당 학술위원이 상주하여 담당 세션의 현 장 상황을 통제/신속하게 응대하였다.

- 본인 노트북으로 발표시, 사전 리허설/테스트 후 연결하였다.

3) 포스터 발표 운영 방식

- 포스터 발표장 앞에 2 명의 운영요원이 기본으로 상주하였 다.

- 포스터 발표 좌장의 no-Show를 대비하여 담당 학술위원 이 상황 체크하였다.

- 포스터 발표장 앞의 보드 및 운영요원을 통해 포스터 탈부 착 시간/발표시간, 발표 보드 위치 등을 확인하였다.

4. 전시

1) 전시개요

- 전시기간: 2013년 6월13일 (목) 6월15일 (토)

- 전시장소: 코엑스 1층 B2 Hall

- 전시규모: 후원 11 개 업체 16 부스

전시 35 개 업체 48 부스(총 64 부스)

2) 전시참가업체

- 참가업체결과: 총 46개 업체(총 64부스)

- 전시 참가국: 총 7 개국(한국, 미국, 일본, 독일, 스위스, 영 국, 싱가폴)

- 전시 참가업체 리스트(Table 6)

3) 기타 전시 및 이벤트 존 운영

(1) 책 전시〈앞에서 기술〉

(2) 인형 전시〈앞에서 기술〉

(3) 이벤트 존

1,000 여명이 넘는 해외 참가자들을 고려하여, 전시장 내 한 국 문화를 소개하고 체험할 수 있는 다양한 이벤트 부스 구성

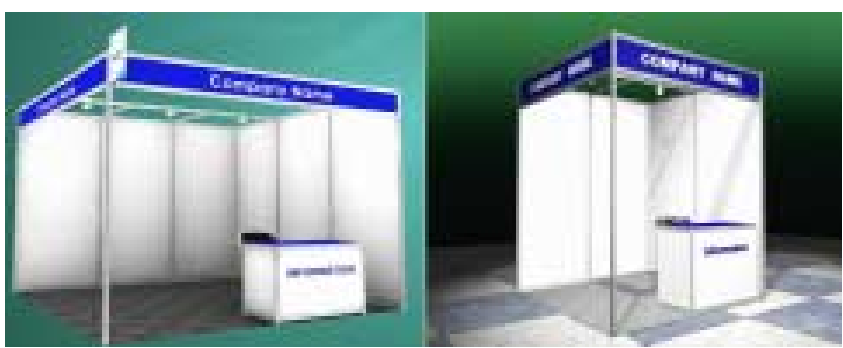

Fig. 4. Types of booth. Standard booth(left) and mini booth(right).

(1) 한국 전통 물품 판매부스 기념 티셔츠 판매(IAPD 로고 프린팅, 한국적 문양 프린 팅) 하회탈 등의 전통 기념품 판매

(2) 한복 체험 부스

전통 궁중한복을 준비하여 병풍을 배경으로 참가자들이 직접 한복을 입어보고, 사진을 촬영할 수 있도록 하였다.

(3) 한국 문화 홍보 부스 정신과 문화에 관한 홍보 책자 배부(역사, 한글, IT 소개 등)

(5) Refresh Zone

휴게 공간이 부족했던 전차대회의 문제점을 보완하기 위해 전시장 내 이동 동선이 많은 포스터 존 앞에 휴게 공간을 여유 있게 구성하였다. 100명이 동시에 앉을 수 있는 테이블을(25개 테이블/4개 의자 셋트)배치하고, 음료도 판매하여 공간을 다용 도로 활용하였다.

4) 전시

기본 부스의 규격은 $3 \mathrm{~m} \times 3 \mathrm{~m} \times 2.5 \mathrm{~m}$ 로 하였으며 미니부 스는 $2 \mathrm{~m} \times 2 \mathrm{~m} \times 2.5 \mathrm{~m}$ 로 하였다(Fig. 4).

(1) 참가자 신청마감

- 조기 신청 마감일 : 2013년 3월 31일

- 참가 신청 마감일 : 2013년 5월 31일

(2) 참가비

- 조기 신청 마감일: 2013년 3월 31일: 4,500,000원

- 참가 신청 마감일 : 2013년 4월 1일 이후: 5,000,000원

(3) 부스의 구성

- 기본부스 제공사항

영문 상호간판 및 부스번호 바닥 파이텍스 설치, 안내데스 크 1 개, 접이식 의자 1 개, 부스당 조명등 $100 \mathrm{~W} 3$ 개, 형광 등 40W 1개, 콘센트(2구) 1개 지급

- 전시자 제공사항

업체 당 점심식사 쿠폰 2장(코엑스 내 WIZWIT), 업체 당 프로그램 북 1 개, 전시출입증 3 장(필요시 추가적인 발급 진행) 지급 
Table 13. Abstract submission statistics by nations

\begin{tabular}{|c|c|c|c|}
\hline Country & No. & Country & No. \\
\hline Republic of Korea & 250 & Belgium & 5 \\
\hline Japan & 78 & Egypt & 5 \\
\hline China & 64 & Canada & 3 \\
\hline India & 36 & Norway & 3 \\
\hline Turkey & 36 & Philippines & 3 \\
\hline United Kingdom & 35 & Poland & 3 \\
\hline Russian Federation & 25 & Venezuela & 3 \\
\hline Malaysia & 19 & France & 2 \\
\hline Taiwan & 22 & Israel & 2 \\
\hline Brazil & 15 & Italy & 2 \\
\hline Thailand & 14 & Libya & 2 \\
\hline Australia & 13 & Portugal & 2 \\
\hline Indonesia & 13 & Switzerland & 2 \\
\hline Nigeria & 12 & Brunei Darussalam & 1 \\
\hline Hong Kong, China & 11 & Greece & 1 \\
\hline United States & 11 & Ireland & 1 \\
\hline Saudi Arabia & 9 & Kazakhstan & 1 \\
\hline Chile & 8 & Latvia & 1 \\
\hline Iran & 8 & Macau & 1 \\
\hline Sweden & 8 & Netherlands & 1 \\
\hline Denmark & 7 & Palestinian & 1 \\
\hline Mexico & 7 & Peru & 1 \\
\hline Singapore & 7 & Qutar & 1 \\
\hline Finland & 6 & Romania & 1 \\
\hline Germany & 6 & Seychelles & 1 \\
\hline Sudan & 1 & Syrian Arab Republic & 1 \\
\hline United Arab Emirates & 6 & Vanuatu & 1 \\
\hline Belarus & 5 & & \\
\hline
\end{tabular}

(4) 부대시설 사용(Table 15)

(5) 신청서 서류

전시업체 디렉토리 신청서, 조립부스 상호간판 신청서, 참가 업체 출입증 신청서, 부대시설 사용 신청서, 가구/비품 사용 신 청서, 위험물 반입(반출) 허가 신청서, 전시품 반입/반출 신청 서, 시간외 전시장 사용신청서

5) 현장 전시국의 운영

Exhibitor service 부스 운영

- 운영 시간: 6월 12일(오전 9시 ) 6월 13일 15일(오전 8시 30분 오후6시)

- 운영 업무: 전시자 문의 응대, 전시품 반출 신청서/시간 외 사용 신청서, 부대시설 시용 신청서, 비품 신청서 접수/결 제, 점심 쿠폰 배부, 명찰 배부, 전시 업체 관리

- 운영 인력: 2 명의 상주 직원 배치(운영요원 포함)

6) 주요 후원사, 전시업체 섭외 현황

주요 후원사는 2011년부터 sponsorship package를 통해 본 격적으로 섭외를 시도하였다. 후원사는 해당년도 예산을 사전
Table 14. Abstract submission statistics by topics

\begin{tabular}{lcccc}
\hline \multicolumn{1}{c}{ Topic } & Oral & Poster & Oral or Poster & Total \\
\hline Cariology & 24 & 41 & 17 & 82 \\
Dental anomalies & 11 & 45 & 15 & 71 \\
Dental anxiety and & 12 & 28 & 6 & 46 \\
$\quad$ behavioral management & & & & \\
Dental materials & 16 & 46 & 3 & 65 \\
Dental Trauma & 8 & 32 & 9 & 49 \\
Endodontics & 13 & 21 & 9 & 43 \\
Epidemiology & 4 & 17 & 2 & 23 \\
Growth and development & 12 & 57 & 10 & 79 \\
- Orthodontics & & & & \\
Oral medicine and pathology & 6 & 29 & 7 & 42 \\
Prevention & 9 & 29 & 5 & 43 \\
Public Health & 7 & 16 & 7 & 30 \\
Special Needs Patients & 13 & 27 & 9 & 49 \\
Syndromes and genetics & 6 & 29 & 12 & 47 \\
Other & 18 & 57 & 11 & 86 \\
Invited Lecture & - & & & 28 \\
\hline & 159 & 474 & 122 & 783 \\
\hline
\end{tabular}

Table 15. Rent fees of facilities for exhibition

\begin{tabular}{lll}
\hline \multicolumn{1}{c}{ 구분 } & 시설 세부 내역 & \multicolumn{1}{c}{ 단가 } \\
\hline 장비구동 및 & $220 \mathrm{~V} / 60 \mathrm{HZ}$ 단상 & 50,000 원 $/ \mathrm{KW}$ \\
\cline { 2 - 3 } 조명용 전기 & 24 시간용 $220 \mathrm{~V}$ 단상 & 70,000 원 $/ \mathrm{KW}$ \\
\hline \multirow{2}{*}{ 전화 } & 국내용 & 50,000 원/대 \\
\cline { 2 - 3 } & 국제용 & 150,000 원/대 \\
\hline 인터넷전용선 & 설치 및 사용료 포함 & 150,000 원/포트 \\
\hline
\end{tabular}

에 확보하기 위해 최소 2012년 12월 전까지 모두 확보하고자 하였고, 전시에 참여했던 국내의 영세한 업체들은 대부분 2013 년 초에 참여를 결정하였다.

(1) 개요

- 후원 package 금액/전시비 확정: 전차 대회들을 참고하여 IAPD 세계대회 기준에 맞는 금액을 책정하였다.

- 후원/전시 업체 보유 DB: 451개 업체 (IAPD 전차대회 후원/전시 업체, $\mathrm{FDI} / \mathrm{EAPD}$ 참여 해외 업체, SIDEX, KIMES 참여 국내 업체 등)

- 후원/전시 컨택 담당자: 조직위원장, 재정 위원장 뿐 아니 라 전 조직위원들이 업체별로 개별적으로 섭외하였다.

(2) 섭외 과정/결과

(1) 부스 마케팅 기회요인

- 영세 업체들이 적은 비용으로 해외마케팅을 할 수 있 는 기회

- 소아치과 분야 마케팅/컨택 루트가 없던 업체들의 신 규 시장 확보

(2) 부스 마케팅 위협요인 
- 경쟁전시회 SIDEX 사전 개최(5월 3일 5일)로 업체 의 부담 가중

- 국내 부스 대비 높게 책정된 부스 비용.

- 소아치과 분야가 주요 마케팅 분야가 아닌 경우가 많음.

- 국내 자체 개발 제품이 아닌 해외 제품 판매사인 경우 해외 참가자 대상 세일즈 할 제품이 없음.

(3) 섭외 루트

- 다양한 경로를 통해 주요 후원사/전시 업체를 섭외함 - 대한소아치과학회 임원, 고문, 회원의 추천 및 개별 섭외

국내에 지사가 없는 글로벌 업체의 경우 IAPD 회 장 (Dr. Alcaino) 및 일본 소아치과학회 회장 (Dr.Yamasaki) 등이 추천 이메일 등을 통해 섭외 에 도움을 주었다.

- IAPD 2013 조직위원회 추천 및 개별 섭외

- 후원/전시 제안서(업체 성격에 맞게 수정/보완) 발송

- IAPD 2013 조직위원회 2차 접촉(전화, 미팅)

- 사무국 섭외(후원 혜택, 절차 안내 등)

7) 협창 및 기관 후원

사무국에서는 주로 지출 예산 축소를 위해 현물 협찬에 집중 하였다. 또한 MICE 산업 관련 정부 기관의 후원 규모 확대를 위해 다양한 안으로 지원금을 신청하였다.

(1) 협찬업체

가비양, 카페베네, 국순당, 화요, 롯데 아이시스

(2) 기관 후원

한국관광공사, 서울관광 마케팅, 강남구청

\section{5. 사교행사}

1) 개막식

(1) 개요

- 일시: 6월 12일(수), 오후 5시 30분 7시

- 장소: 코엑스 3층 오디토리움(극장식 1,058석)

- 참석자: 등록자 약 950 명

- 참가비용: 등록비에 포함됨(전 참가자 참석 가능)

- 참석 VIP: 박원순 서울시장, 김춘진 국회의원, 알비노 말 룽구 주한 앙골라 대사, 김세영 대한치과협회 회장, 김경욱 대한치의학회 부회장, 백승호 대한장애인치과학회 회장, 김한술 대한치과기재협회 회장, 기타 후원사 대표( $3 \mathrm{M}$ $\mathrm{ESPE}$, 신흥, $\mathrm{GC}$ 코리아)

- 공연: 샌드에니메이션, 어린이 브라스밴드, 어린이 상모 + 사물놀이
(2) 식의 컨셉

대회의 격을 높이기 위해 관련 VIP를 초청하여 해외 참가자 들에게 국내 소아치과의 위상을 알리고자 하였다. 대회의 시작 을 알리는 개회식의 컨셉은 소아치과인들의 축제의 장을 알리 는 흥겨운 분위기와 자긍심을 느낄 수 있는 스토리 있는 공연들 로 구성하였다.

Roll Call of Nation의 경우 사전 IAPD 본부와 충분히 communication을 하여 전례없던 구성으로 진행하였다.

1 부는 Roll Call of Member Association(IAPD 국가 회원 학회 소개)로, 2부는 Roll Call of Non-Member Association (IAPD 비회원 국가 소개) 로 구성하여 참가국들을 모두 소개 하고 국가명에 민감한 국가들(중국, 대만)의 갈등을 최소화 할 수 있었다.

오디토리움의 대형 스크린을 와치 아웃 시스템을 세 개의 화 면 분할로 나눠 진행하여, 중계 화면/간지 슬라이드 화면 등이 다채롭게 구성될 수 있게 하였다.

2) Welcome reception

(1) 개요

- 일시: 6월 12일(수), 오후 7시 8시 30분

- 장소: 코엑스 3 층 오디토리움 로비(최대 약 700 명 수용)

- 참석자: 등록자 약 950 명

- 참가비용: 등록비에 포함됨(전 참가자 참석 가능)

- 공연: 사물놀이, 비빔밥 퍼포먼스

- 식음료: 워커힐 케이터링 스탠딩 리셉션(칵테일 리셉션 /light food), 칵테일 제공(1,000잔), 떡볶이/비빔밥 300 인분/화요 시음

\section{(2) 컨셉}

캐주얼한 스탠딩 리셉션으로 진행함. 전차대회 경험 등에 비 추어 무겁지 않은 음식들로 구성하기로 하였다. 음식이 부족한 부분은 떡볶이와 비빔밥을 통해 보완하기로 하였다. 칵테일 수 요가 예상보다 많았고, 외국인들이 비빔밥 이벤트에 큰 관심을 보였다. 사물놀이 팀을 활용하여 오디토리움 안에 있던 참가자 들을 자연스럽게 로비로 유도하였다.

3) Gala dinner

(1) 개요

- 일시: 6월 14일(금), 오후 7시 10시

- 장소: 워커힐 명월관 정원(최대 340 명 수용)

- 참석자: 신청자 약 340 명

- 참가비용: 별도 등록 $\$ 110$

- 공연: 칵테일 쇼, 퓨전재즈그룹, 서울대 댄스팀, 강강수월래

- 식음료: 워커힐 $\mathrm{BBQ}$ 뷔페(채식주의자를 위한 샐러드/야 채 구이 메뉴 포함), 와인 1잔 제공, 칵테일 300잔 제공 (칵테일 쇼에 포함), 맥주 무제한 제공

- 드레스코드: 스마트 캐주얼 


\section{(2) 컨셉}

여름 밤 야외 파티를 컨셉으로 캐쥬얼한 컨셉으로 진행하였 다. 한강 야경과 한옥 가든으로 한국적인 분위기를 연출하고, 다함께 참여할 수 있는 공연들로 흥겨운 분위기를 만들고자 하 였다.

\section{4) 폐회식}

(1) 개요

- 일시: 6월 15일(토), 오후 4시 30분 5시 30분

- 장소: 코엑스 1 층 그랜드볼룸 103 호

- 참석자: 등록자 약 370 명

- 참가비용: 등록비에 포함됨(전 참가자 참석 가능)

- 공연: 사진 슬라이드 쇼, IAPD 깃발 전달식, 차기대회 홍 보 공연

\section{(2) 컨셉}

클로징은 4 일간의 대회 기간동안을 스케치한 사진 슬라이드 영상을 중심으로 마무리 하는 컨셉으로 진행하였다. IAPD의 깃발을 상징적인 의미의 선물로 제작하여, IAPD 2013 조직위 원장/현 $\mathrm{IAPD}$ 회장/차기 $\mathrm{IAPD}$ 회장/차기 대회 조직위원장에 게 전달하는 의미있는 깃발 전달식을 거행하였다.

$\mathrm{IAPD}$ 또한 현 집행부가 차기 집행부를 소개하며 다음 만남 을 기약하는 과정이 있었다.

5) Farewell party

(1) 개요

- 일시: 6월 15일(토), 오후 7시 9시 30분

- 장소: 삼청각 일화당 정원

- 참석자: 등록자 213 명

- 참가비용: 별도 등록 $\$ 70$

- 공연: 별도 공연 없음

- 식음료: 한정식 코스, 백세주 100병, 맥주

\section{(2) 컨셉}

Farewell Party는 마지막 날을 마무리하는 자리인 만큼, 공 연이나 별도의 이벤트 없이 조용히 사교할 수 있는 분위기를 조 성하였다.

코엑스에서 약 40 분 소요되는 곳에 위치하고 있는 단점이 있 지만, 북한산이 둘러싸고 있는 고즈넉한 분위기와 대회 기간동 안 제공되지 않았던 한식 코스 요리에 많은 해외 참가자들이 만 족해 하였다.

\section{6. 숙박}

1) 개요

- 룸 블럭: 2012년 1월 코엑스 주변 룸 블럭(1180개 룸 블럭)

- 운영: Housing Bureau를 통해 예약/예약 컨펌/취소 진행

- 예약방법: 온라인/오프라인 폼 이용
- 특이사항: 중국, 일본, 유럽 국가에서 단체로 올 경우 대부 분 자국 내 여행사를 통해 항공과 숙박을 함께 예약하였다. 이 경우 housing bureau를 통하지 않고 직접 예약을 하거 나, 코엑스와 멀리 떨어져 있더라도 관광 중심 지역에 호텔 을 예약하였다.

코엑스 주변 호텔들의 숙박료가 비싼 편이라, 저렴한 숙소 에 대한 정보를 요청하는 해외 참가자가 많아, 일일 평균 3 5만원 대의 저렴한 Guest House 정보를 홈페이지에 별도로 게재하고, 참가자가 직접 예약할 수 있도록 안내하 였다.

2) 호텔 리스트(Table 16)

아래의 호텔에 총 1,180 개의 방을 block하였다.

\section{7. 관광}

1) 개요

- 관광 신청 대상: 사전 및 현장 관광 프로그램 신청 해외참가자

- 관광 안내데스크 운영시간: 6월 12 (수) 6월15일(토) 8:30 18:00

- 관광 안내데스크 장소: 코엑스 1층 그랜드볼룸 앞

- 사전업무: 사전 및 현장 관광 프로그램 안내/예약

- 관광 현장 업무: 현장 관광프로그램 운영 여행사(코스모 진) 담당자가 데스크에 상주하여 문의 응대함.

- 관광 현장 인력 사전투어신청 담당: 킴스여행사 직원 1명 (12일) 현장투어신청 담당: 코스모진여행사 직원 3명 (12 15일)

2) 프로그램

- 사전 예약: 서울모닝투어에서 주관하였으며 경비는 1 인당 95,000 원이고 참가 최소인원이 10 명으로 6월 13 일 하루 동안만 운영하였다.

- 현장 예약: 총 14 개 투어가 운영되었으며 경비는 46,550 원 (한국문화체험투어)부터 769,500원 (제주투어)이었고 최소 참가인원은 tour에 따라 1 4명이었으며 대회기간 동 안 운영하였다.

Table 16. Hotel lists of room blocking for 2013 IAPD congress

\begin{tabular}{clcc}
\hline & 호텔명 & 학회장 거리 & 등급 \\
\hline 1 & Grand InterContinental Seoul & 도보 5분 & $\star \star \star \star \star$ \\
2 & InterContinental Seoul Coex & 도보 5분 & $\star \star \star \star \star$ \\
3 & Oakwood Premeir Coex Center & 도보 5분 & $\star \star \star \star \star$ \\
4 & Ramada Seoul & 차량 10분 & $\star \star \star \star$ \\
5 & Hotel Riviera & 차량 15분 & $\star \star \star \star$ \\
6 & Ellui Hotel & 차량 15분 & $\star \star \star \star$ \\
7 & Hotel Prima Seoul & 차량 15분 & $\star \star \star \star$ \\
8 & Hotel La Mir & 차량 10분 & $\star \star \star$ \\
9 & Ibis Seoul(Gangnam) & 도보 15분 & $\star \star \star$ \\
10 & Casaville Samsung Seoul & 도보 10분 & 레지던스 \\
\hline
\end{tabular}




\section{2) 운영}

사전에 운영했던 관광프로그램은 "대회 참가자" 들로만 구성 된 private 관광과 체험 위주로 이루어졌기 때문에, 가격 경쟁 력이 높지 않았다.

이에 사전 신청이 저조하여, 현장에서는 일반 투어 참가자들 과 함께 움직이는 대신 가격 경쟁력이 좋은 프로그램들로 구성 하여 하루 전에 예약해도 바로 출발할 수 있는 형태로 편의성을 높여 참가자들에게 호응이 좋았다. 북한과의 긴장 상태에도 불 구하고 DMZ 투어의 인기가 높았다.

8. 인력

1) 진행 요원의 선발

• 채용공고: 2013년 5월13일 5월24일까지

- 채용대상: 컨벤션 운영요원 경험이 있는 외국어 가능자를 우대

- 전형방법: 1 차 서류심사(이력서)

2차 사전교육을 통한 면접심사

Table 17. Placards, banners and sign boards in Seoul IAPD congress

\begin{tabular}{|c|c|c|c|c|}
\hline & 위치 & 형태 & 크기 & 수량 \\
\hline \multirow{7}{*}{ 외부 } & 공항 & 실사 출력(유포지) & $147.5 \mathrm{~cm} \times 33.2$ & 1 \\
\hline & & $X$ 배너 & $0.6 \mathrm{~m} \times 1.8 \mathrm{~m}$ & 1 \\
\hline & & 피켓 & $45 \mathrm{~cm} \times 55 \mathrm{~cm}$ & 3 \\
\hline & President's Dinner & I 배너 & $2 \mathrm{~m} \times 2.2 \mathrm{~m}$ & 1 \\
\hline & Gala Dinner & 난간 현수막 & $9.8 \mathrm{~m} \times 1.2 \mathrm{~m}$ & 1 \\
\hline & Farewell Party & 세로현수막 & $253 \mathrm{~cm} \times 280 \mathrm{~cm}$ & 1 \\
\hline & & 세로현수막 & $700 \mathrm{~cm} \times 90 \mathrm{~cm}$ & 1 \\
\hline \multirow[t]{2}{*}{ 지하 1 층 } & 코엑스몰 & $\mathrm{X}$ 배너 & $0.6 \mathrm{~m} \times 1.8 \mathrm{~m}$ & 5 \\
\hline & & $\mathrm{X}$ 배너 & $0.6 \mathrm{~m} \times 1.8 \mathrm{~m}$ & 3 \\
\hline \multirow[t]{27}{*}{1 층 } & GRB $101+102$ & 통천배너 & $7.5 \mathrm{~m} \times 5 \mathrm{~m}$ & 1 \\
\hline & & 포디움타이틀 & $70 \mathrm{~cm} \times 20 \mathrm{~cm}$ & 1 \\
\hline & & 폼보드 & $45 \mathrm{~cm} \times 65 \mathrm{~cm}$ & 1 \\
\hline & GRB 103 & 세로현수막 & $1.5 \mathrm{~m} \times 4.5 \mathrm{~m}$ & 2 \\
\hline & & 포디움타이틀 & $70 \mathrm{~cm} \times 20 \mathrm{~cm}$ & 1 \\
\hline & & 폼보드 & $45 \mathrm{~cm} \times 65 \mathrm{~cm}$ & 2 \\
\hline & GRB 104 & 세로현수막 & $1.5 \mathrm{~m} \times 4.5 \mathrm{~m}$ & 2 \\
\hline & & 포디움타이틀 & $70 \mathrm{~cm} \times 20 \mathrm{~cm}$ & 1 \\
\hline & GRB 105 & 세로현수막 & $1.5 \mathrm{~m} \times 4.5 \mathrm{~m}$ & 2 \\
\hline & & 세로현수막 & $1.5 \mathrm{~m} \times 4.5 \mathrm{~m}$ & 2 \\
\hline & & 가로현수막 & $9 \mathrm{~m} \times 1 \mathrm{~m}$ & 1 \\
\hline & & 포디움타이틀 & $70 \mathrm{~cm} \times 20 \mathrm{~cm}$ & 1 \\
\hline & GBR 로비 상단 & 가로현수막 & $20 \mathrm{~m} \times 3.6 \mathrm{~m}$ & 1 \\
\hline & GBR 로비 맞은편 & 세로현수막 & $1.8 \mathrm{~m} \times 6 \mathrm{~m}$ & 6 \\
\hline & 행사장 안내 & 현수막 & $1.5 \mathrm{~m} \times 2.5 \mathrm{~m}$ & 2 \\
\hline & 포토월 & 목공 & $2 \mathrm{~m} \times 2.2 \mathrm{~m}$ & 1 \\
\hline & 에스컬레이터 & $\mathrm{X}$ 배너 & $0.6 \mathrm{~m} \times 1.8 \mathrm{~m}$ & 2 \\
\hline & Q\&A Lounge & $\mathrm{X}$ 배너 & $0.6 \mathrm{~m} \times 1.8 \mathrm{~m}$ & 2 \\
\hline & 복도 & X배너 & $0.6 \mathrm{~m} \times 1.8 \mathrm{~m}$ & 1 \\
\hline & & $\mathrm{X}$ 배너 & $0.6 \mathrm{~m} \times 1.8 \mathrm{~m}$ & 1 \\
\hline & & $\mathrm{X}$ 배너 & $0.6 \mathrm{~m} \times 1.8 \mathrm{~m}$ & 1 \\
\hline & & $\mathrm{X}$ 배너 & $0.6 \mathrm{~m} \times 1.8 \mathrm{~m}$ & 1 \\
\hline & & X배너 & $0.6 \mathrm{~m} \times 1.8 \mathrm{~m}$ & 3 \\
\hline & & $\mathrm{X}$ 배너 & $0.6 \mathrm{~m} \times 1.8 \mathrm{~m}$ & 3 \\
\hline & & $\mathrm{X}$ 배너 & $0.6 \mathrm{~m} \times 1.8 \mathrm{~m}$ & 1 \\
\hline & Preview Room & 룸사인보드 & $50 \mathrm{~cm} \times 40 \mathrm{~cm}$ & 1 \\
\hline & Speakers Ready Room & 룸사인보드 & $50 \mathrm{~cm} \times 40 \mathrm{~cm}$ & 1 \\
\hline
\end{tabular}

- 사전교육: 6월 7일(금) 코엑스 208호

전체교육과 파트별 분과 교육 실시

• 리허설 교육: 6 월 12 일 오전 및 오후(등록 및 학술 운영요원)

2) 공항 안내데스크 운영 요원

- 채용공고: 진행요원 지원자와 동일하나 모집요강은 따로 기재하였다.

- 채용대상: 진행요원 지원자 중 외국어 특기자를 공항 안내 데스크 운영요원으로 사전 선발하여 투입하였다.

- 사전교육: IAPD 학술대회의 전반적인 이해와 참가자들의 편의를 고려한 사항들을 정리한 자료를 제공하여 현장에서 실용적인 안내가 가능하도록 하였다. 추가적인 문의 시, 사 무국과 연계하여 실시간으로 현장응대가 가능하도록 조치 하였다.

9. 인쇄, 제작물, 기념품

1) 제작물 (Table 17)

\begin{tabular}{|c|c|c|c|c|}
\hline & 위치 & 형태 & 크기 & 수량 \\
\hline \multirow[t]{22}{*}{$\overline{2 F}$} & \multirow[t]{2}{*}{203} & 세로현수막 & $0.9 \mathrm{~m} \times 2.8 \mathrm{~m}$ & 2 \\
\hline & & 포디움타이틀 & & 1 \\
\hline & \multirow[t]{2}{*}{208} & 세로현수막 & $0.9 \mathrm{~m} \times 2.8 \mathrm{~m}$ & 2 \\
\hline & & 포디움타이틀 & & 1 \\
\hline & \multirow[t]{2}{*}{201} & 가로현수막 & $6 \mathrm{~m} \times 0.9 \mathrm{~m}$ & 1 \\
\hline & & 포디움타이틀 & & 1 \\
\hline & 공배너 & $\mathrm{X}$ 배너 & $0.6 \mathrm{~m} \times 1.8 \mathrm{~m}$ & 2 \\
\hline & \multirow[t]{3}{*}{ 복도 } & $\mathrm{X}$ 배너 & $0.6 \mathrm{~m} \times 1.8 \mathrm{~m}$ & 2 \\
\hline & & $\mathrm{X}$ 배너 & $0.6 \mathrm{~m} \times 1.8 \mathrm{~m}$ & 2 \\
\hline & & $\mathrm{X}$ 배너 & $0.6 \mathrm{~m} \times 1.8 \mathrm{~m}$ & 2 \\
\hline & 201 & I 배너 & $1 \mathrm{~m} \times 2 \mathrm{~m}$ & 1 \\
\hline & 201 & 룸사인보드 & $\mathrm{A} 3$ & 1 \\
\hline & $202 \mathrm{~A}$ & 룸사인보드 & $\mathrm{A} 3$ & 1 \\
\hline & $202 \mathrm{~B}$ & 룸사인보드 & A3 & 1 \\
\hline & 203 & 룸사인보드 & A3 & 1 \\
\hline & 204 & 룸사인보드 & $\mathrm{A} 3$ & 1 \\
\hline & 205 & 룸사인보드 & A3 & 1 \\
\hline & 206 & 룸사인보드 & A3 & 1 \\
\hline & 208 & 룸사인보드 & A3 & 1 \\
\hline & 208 & 룸사인보드 & $\mathrm{A} 3$ & 1 \\
\hline & $203 \mathrm{~A}$ & 폼보드 & $45 \mathrm{~cm} \times 65 \mathrm{~cm}$ & 1 \\
\hline & 204 & 폼보드 & $45 \mathrm{~cm} \times 65 \mathrm{~cm}$ & 2 \\
\hline \multirow[t]{6}{*}{$3 \mathrm{~F}$} & \multirow[t]{3}{*}{ 오디토리움 로비 } & 가로 현수막 & $15.4 \mathrm{~m} \times 1 \mathrm{~m}$ & 1 \\
\hline & & 세로현수막 & $1.8 \mathrm{mx} 7.5 \mathrm{~m}$ & 2 \\
\hline & & 포디움타이틀 & & 3 \\
\hline & \multirow[t]{2}{*}{ R1 } & $\begin{array}{l}\text { 갈라 President } \\
\text { dinner 재활용 }\end{array}$ & & \\
\hline & & 현수막 & $4.5 \mathrm{~m} \times 0.8 \mathrm{~m}$ & 1 \\
\hline & 에스컬레이터 & $\mathrm{X}$ 배너 & $0.6 \mathrm{~m} \times 1.8 \mathrm{~m}$ & 2 \\
\hline \multirow{5}{*}{$\begin{array}{l}\text { 전시장 } \\
\text { (B2) } \\
\text { (전시팀) }\end{array}$} & 입구 & 입구현판 & $12 \mathrm{~m} \times 1.08 \mathrm{~m}$ & 1 \\
\hline & 전시장 내부 & 세로배너 & $1.8 \mathrm{~m} \times 4 \mathrm{~m}$ & 4 \\
\hline & Poster Area & I배너 & $1.8 \mathrm{~m} \times 2 \mathrm{~m}$ & 1 \\
\hline & Poster Area & I배너 & $1 \mathrm{~m} \times 2 \mathrm{~m}$ & 3 \\
\hline & 커피 브레이크 & $\mathrm{X}$ 배너 & $0.6 \mathrm{~m} \times 1.8 \mathrm{~m}$ & 2 \\
\hline \multirow[t]{2}{*}{ 그외 } & 공배너 & $\mathrm{X}$ 배너 & $0.6 \mathrm{~m} \times 1.8 \mathrm{~m}$ & 2 \\
\hline & & 유포지 & $\mathrm{A} 3$ & 8 \\
\hline
\end{tabular}


Table 18. Published materials and plates in Seoul IAPD congress

\begin{tabular}{llcc}
\hline & 물품명 & 크기 & 수량 \\
\hline & 프로그램북 & $\mathrm{a} 4$ & 1,800 \\
& 포켓북 & & 2,000 \\
& 포스터 & 200 \\
학술 & 연자 감사패 & & \\
& 초청연사, 좌장 감사장 & & \\
& CE 확인증 & $\mathrm{a} 4$ & 2,000 \\
& 명패 내지 & & \\
& 명패 & & \\
& Gala Dinner 초청장 & 400 \\
& Farewell party 초청장 & & 200 \\
& Presiential Dinner 초청장 & & 50 \\
& Opening Ceremony 초청장 & & 2,000 \\
& 국내 VIP 개회식 초청장 & \\
부대행사 & & 1,800 \\
& 런치쿠폰 & 300 \\
\hline & 위즈윗 쿠폰 & \\
\hline
\end{tabular}

Table 19. The souvenirs for participants, guest speakers, and VIP

\begin{tabular}{lllr}
\hline & \multicolumn{1}{c}{ 내용 } & 비고 & 수량 \\
\hline \multirow{4}{*}{ 기념품잠(한국어) } & VIP & 26 개 \\
& 자개명함집/usb 셋트 & 초청연자 & 150 개 \\
& 하회탈 액자 & 일본 $\mathrm{MOU}$ 참석자 & 20 개 \\
& Welcome Kit & 해외참가자 & 400 개 \\
\hline
\end{tabular}

2) 인쇄물(Table 18)

3) 기념품(Table 19)

10. 기타

1) 해외 참가자 서비스 제공

(1) 인천공항 안내데스크 운영

- 운영기간: 2013년 6월9일(일) 6월12일(수)

- 주요업무: 교통 안내(인천공항 $\rightarrow$ 숙소/코엑스), 대회정보 안내, 초청 연자 공항버스 티켓 전달

- 평가: 인천공항이 낯선 참가자들에게 교통에 대한 안내를 $1: 1$ 로 응대해 주어 해외 참가자들에게 큰 도움이 되었다.

(2) 인천공항 수하물 픽업장소 웰컴 메세지

- 운영기간: 2013년 6월8일 6월13일

- 운영장소: 인천공항 수하물 픽업장소 전체

- 주요내용: IAPD 2013 공항 안내데스크 위치 안내, 웰컴 메시지 게재
(3) VIP pick-up service 제공

- 운영대상: 보드 멤버 포함 총 19 명

- 주요업무: 공항픽업서비스 전문 제공업체를 통해(에쿠스) 차량을 이용한 의전. 공항 안내데스크의 운영요원 1 인과 영접 기사가 피켓으로 환영, 호텔까지 픽업함.

(4) 통역 서비스 제공

- 제공대상: 일본인 참가자 $($ 영어 $\rightarrow$ 한국어 $\rightarrow$ 일본어 $)$

- 제공세션 : 13 일, 14 일 기조강연

$$
\text { V. 요 약 }
$$

2013년 6월 서울에서 개최된 제 24회 세계소아치과학회는 대회 참가자 1,800 여명, 일반 연제 발표 700 건 이란 역대 대회 사상 최고의 기록을 수립하는 양적인 성과를 기록하였다. 또한 학술프로그램의 내용과 대회의 운영 면에서도 모든 참가자에게 좋은 평가를 받아 질적인 면에서도 성공을 거둔 대회였다.

이번 학술대회의 전체적인 학술프로그램은 "New visions for Pediatric Dentistry" 이란 주제 하에 최근 소아치과학의 경 향을 반영해 미래의 소아치과학의 변화와 흐름을 조망해보고 소아치과 의사들의 역할을 제시하였다.

대한소아치과학회는 이번 세계학회를 통해 우리학회의 높은 학문적 - 임상적 수준, 유구한 전통, 탄탄한 조직력을 세계에 알 렸다. 이번 세계학회를 통하여 앞으로 우리 학회 회원, 교수들 이 보다 적극적으로 국제무대에서 활동할 수 있는 계기를 마련 하였다.

\section{감사의 말슴}

그동안 제 24 회 서울 세계소아치과학회의 성공적인 개최를 위 해 많은 관심과 협조, 성원을 보내 주신 대한소아치과학회 개원 의 선생님, 고문님, 학회장님을 비롯한 임원님, 조직위원님, 그 리고 업체 대표님과 Coex $\mathrm{PCO}$ staff들에게, 조직위원장으로 서, 진심으로 감사의 말씀을 드립니다.

\section{References}

1. History and organization of International Association of Paediatric Dentistry available from URL : http://www.iapdworld.org/main.php.

2. Board directors of IAPD : Council and board director's requirements and guidelines for the organization of the biennial congress of IAPD, revised in 2009, International Association of Paediatric Dentistry, 1-24, 2009.

3. IAPD Council : Report: IAPD 2011, International Association of Paediatric Dentistry, 1-50, 2011.

4. Donly K, Thomas J : $19^{\text {th }}$ congress of the 
International Association of Paediatric Dentistry hosted by AAPD, Blackwell Munksgaard, 1-68, 2003.

5. Local organizing committee of $20^{\text {th }}$ IAPD Congress : Final report: IAPD 2005-Frontiers of Paediatric Dentistry, CMS Australia, 1-35, 2005.

6. Local organizing committee of $21^{\text {st }}$ IAPD Congress : Program book: 2007 Hong Kong IAPD congress, Hong Kong Society of Pediatric Dentistry, 1-97.
2007.

7. Local organizing committee of $22^{\text {nd }}$ IAPD Congress : Program book: 2009 German IAPD congress, Germany Society of Pediatric Dentistry, 1-120. 2009.

8. Local organizing committee of $23^{\text {rd }}$ IAPD Congress, Congress final report: $23^{\text {rd }}$ congress of the International Association of Paediatric Dentistry, The Helenic Society of Paediatric Dentistry, 2011. 


\title{
국문초록
}

\section{제 24회 서울 세계소아치과학회 개관(概觀)}

\author{
이상호 \\ 조선대학교 치의학전문대학원 소아치과학교실 \\ 제24회 서울 세계소아치과학회 조직위원회
}

대한소아치과학회 주관으로 제 24회 세계소아치과학회가 2013년 6월 12일 15일 서울 코엑스에서 성공적으로 개최되었 다. 이번 학술대회의 주제는 "New visions in Pediatric Dentistry" 로 세계 67개국에서 1,855명이 참석하여 가장 많은 인 원이 참석하는 기록을 남기게 되었다. 85 명의 연자가 초청되었으며 일반 연재도 700 여편이 발표되어 학술적으로도 풍성한 수확을 거두었다.

이번 대회는 한국의 지리적 여건과 북한의 미사일 발사 위협에 따른 좋지 못한 여건에서도 943 명의 외국인인 참석하여, 그 동안의 한국 소아치과학회의 국제무대에서의 높은 위상을 보여주었다. 또한 저개발 국가에서도 100 여명이 참석하여 국가간 소아치과의사의 유대관계를 형성하는데 많은 기여를 하였다. 참석자들은 그 양과 질 면에서 학술프로그램을 매우 높게 평가 하였다. 이와함께 각종 사교행사에도 많이 참석하여 한국의 따뜻한 환대와 전통과 현대가 아우러진 문화, 그리고 음식을 마 음껏 즐겼다.

대한소아치과학회는 이번 세계학회를 통해 우리 학회의 높은 학문적, 임상적 수준, 유구한 전통, 탄탄한 조직력을 세계에 알리게 되었다. 이번 세계학회의 성과가 여기서 끝나지 않고 이를 통하여 앞으로 우리 회원, 교수들이 보다 적극적으로 국제 무대에서 활동할 수 있는 계기가 되어야 한다.

주요어: 세계소아치과학회, 학회, 서울, 소아치과 